\title{
SYNERGISTIC ABILITY OF PSf AND PVDF TO DEVELOP HIGH-PERFORMANCE PSf/PVDF COATED MEMBRANE FOR WATER TREATMENT
}

\author{
N. Kusumawati ${ }^{1, *}$, P. Setiarso ${ }^{2}$, S. Muslim ${ }^{3}$ and N. Purwidiani ${ }^{4}$ \\ ${ }^{1,2}$ Department of Chemistry, Universitas Negeri Surabaya, \\ Ketintang Surabaya 60231, (East Java) Indonesia \\ ${ }^{3}$ Department of Electrical Engineering, Universitas Negeri Surabaya, \\ Ketintang Surabaya 60231, (East Java) Indonesia \\ ${ }^{4}$ Department of Family Welfare Education, Universitas Negeri Surabaya, \\ Ketintang Surabaya 60231, (East Java) Indonesia \\ *E-mail: nkusumawati82@yahoo.com
}

\begin{abstract}
In this study, asymmetric polysulfone (PSf)/polyvinylidene fluoride (PVDF) coated membranes were prepared from $\mathrm{PSf} / \mathrm{NMP} / \mathrm{NH}_{4} \mathrm{Cl}$ and $\mathrm{PVDF} / \mathrm{NMP} / \mathrm{NH}_{4} \mathrm{Cl}$ system via phase inversion induced by immersion precipitation. Effect of stirring time and cast thickness on morphology, mechanical strength, and pure water permeability of the prepared membranes were systematically studied by scanning electron microscopy (SEM), tensile tester and dead-end filtration experiments. The results demonstrated that the elevation in the stirring time resulted in higher porosity and greater formation of smaller pore sizes, which attributed to higher Young's modulus and comparable pure water permeability. The casting with different thicknesses was done in this study. It was shown that pores on the membrane surface become larger in size with an increase of cast thicknesses. At the same time, the porosity of the membranes was gradually reduced. When the 7 hours stirring time and $0.4 \mathrm{~mm}$ cast thickness was used in preparation, the membranes exhibited the excellent pure water permeability. In general, PSfPVDF coated membranes have an increased thermal resistance as the stirring time and casting thickness increases. In addition, chemical resistance analysis results showed higher acid resistance and lower alkaline resistance of the prepared membranes. On the whole, adjusting stirring time and cast thicknesses is an effective approach to tailor the mechanical strength, performance, thermal and also chemical resistance of the formed PSf/PVDF coated membranes.
\end{abstract}

Keywords: membranes; coating; polysulfone; polyvinylidene fluoride; composite

() RASĀYAN. All rights reserved

\section{INTRODUCTION}

Over the past three decades, polymeric membranes have become the main focus of many physicists, chemists, and biotechnical scientists due to the selective and proficient separation properties without the use of additional chemicals. ${ }^{1-5}$ The conventional operation of the membrane-based technology is superior to other methods such as adsorption and distillation. ${ }^{6}$ The membrane process that uses pressure as a driving force such as microfiltration (MF), ultrafiltration (UF), and nanofiltration (NF) have been widely used because of strong demand for a large number of industrial applications such as purification, seawater desalination, wastewater treatment and reuse, food processing and bioseparation. ${ }^{5,7-10}$ In addition, NF technology is reported to be efficient in the separation of organic micro-pollutants, while the main disadvantage of this technology is its high energy consumption due to the high operational pressures. ${ }^{6,11-15}$ On the other hand, the separation performance by MF and UF is limited by large pore size despite relatively lower operational pressure. To achieve a more cost-effective and efficient separation technology, the development of advanced membrane materials with a relatively high selectivity and low operational pressure is needed. 
There are a number ways of preparing porous polymeric membranes, but most of the membranes are prepared using controlled phase inversion of a homogeneous polymer solution which will result in two phases: one with high (polymer-rich phase) and the other with a low polymer concentration (polymerpoor phase). The polymer-rich phase will form the membrane matrix, while the polymer-poor phase will form membrane pores.

The concentrated phase solidifies shortly after phase separation, thus forming the membrane. ${ }^{16}$ The performance of the membrane separation prepared by this process is determined by the morphology formed during the phase inversion process and the subsequent solidification. In addition, the phase inversion process has been widely used for the preparation of most membranes with symmetric and asymmetric structures. ${ }^{17-18}$ Based on a number of different driving forces of the phase inversion, there are two main techniques that induce phase inversion processes, i.e., nonsolvent induced phase separation (NIPS), and thermally introduced phase separation (TIPS). ${ }^{19-20}$

During the NIPS process, the polymer solution is cast as a thin film and subsequently immersed in a nonsolvent bath. Precipitation occurs due to non-solvent diffusion into the casting solution during the phase inversion process to replace the presence of a solvent. The good solvent in the polymer solution is exchanged for the non-solvent. ${ }^{16}$ The rapid exchange between solvent and nonsolvent results in the phase inversion, which is beneficial for the formation of the dense skin layer and fingerlike structures in the sublayer, often results in the poor mechanical property and permeation performance. ${ }^{21}$ Therefore, the improvement of the NIPS method is very important, which involve chemical, irradiation and blending modification. ${ }^{22-25}$ However, all these methods have made the membrane formation process more complicated.

Polysulfone (PSf) has excellent chemical resistance almost an entire range of $\mathrm{pH}$ (2-13) and oxidative medium (5-7\% hypochlorite, hydrogen peroxide 3-5\%). ${ }^{26-30}$ However, PSf tends to form symmetry structures with high mass transfer resistance so that the fouling tendency becomes higher than the asymmetric membrane. In addition, the PSf membrane has a characteristical structure with large pore diameter but with a highly porous layer thickness. This is the cause of the relatively low permeability of the PSf membrane compared to other commercial membranes, such as PVDF.

Polyvinylidene fluoride (PVDF) is resistant to almost all organic and inorganic acids, also oxidative medium. However, the excellent chemical stability of PVDF does not particularly apply to strong base solutions or to esters and ketones. ${ }^{31-34}$ Contrary, the PVDF membrane structure has a relatively small pore diameter, with a low porous layer thickness.

In our earlier reported work, there has been a polymer blending between PSf and PVDF using NMP solvents and $\mathrm{NH}_{4} \mathrm{Cl}$ porogen additives. The results obtained from SEM cross-sectional analysis shows that the obtained PSf/PVDF blended membrane has a large macrovoid volume in the membrane porous layer. This is because the low solubility of $\mathrm{NH}_{4} \mathrm{Cl}$ in the $\mathrm{NMP}$ solvent has resulted in the agglomeration of the particles at certain locations on the membrane, thus preventing the formation of large vacant space when the non-solvent phase inversion/phase separation is performed. ${ }^{28}$

The condition has caused the membrane to have poor mechanical property. Based on these observations, in our current work PSf MF membranes (our earlier reported work) were modified using a different method, i.e. blending, in order to know the weakness and strengths of PSf membrane modification process using blending and coating in producing a composite membrane with a relatively high performance and low operational pressure. From our earlier study, the well-performed composition of PSf and $\mathrm{PVDF}$, each i.e. 10\% $\mathrm{PSf} / 84 \% \mathrm{NMP} / 6 \% \mathrm{NH}_{4} \mathrm{Cl}$ (wt. $\%$ ) and $16 \% \mathrm{PVDF} / 84 \% \mathrm{NMP} / 0 \% \mathrm{NH}_{4} \mathrm{Cl}$ (wt. $\%$ ) was selected for membrane preparation. The coated PVDF into the PSf membrane matrix was confirmed by FT-IR spectroscopy. ${ }^{28}$

The coating process was done with wet coating method to avoiding the reconstitution of PSf in the NMP solvent present in the PVDF casting solution (coating agent). The difference in surface and crosssectional morphology of the membranes due to the different stirring time and cast thickness was determined by Scanning Electron Microscope. The mechanical strength and performance of the modified membranes each were measured in term of pure water flux. 


\section{RASĀYAN J. Chem.}

Vol. 11 | No. 1 | 260 - 279 | January - March | 2018

Material and Methods

\section{EXPERIMENTAL}

Polysulfone (PSf) (Mw 35,000) and 1-Methyl-2-pyrrolidone (NMP) (biotech grade, $\geq 99.7 \%$ ) used throughout this whole study were purchased from Sigma Aldrich Singapore. Polyvinylidene fluoride (PVDF) (Mw 354,000) was purchased from Aldrich Singapore. Ammonium chloride $\left(\mathrm{NH}_{4} \mathrm{Cl}\right)(\geq 99.5 \%)$, obtained from Riedel de Haen China, was used as a pore forming additive. Gauze fabric material (254 mesh), purchased from Kasa Husada Indonesia, was used as membrane supporting layer.

\section{General Procedure of Membrane Preparation}

Asymmetric flat sheet PSf/PVDF coated membranes were prepared by phase inversion. $\mathrm{PSf}$ and $\mathrm{NH}_{4} \mathrm{Cl}$ each with a mass ratio of $14 \mathrm{wt} . \%$ and $2 \mathrm{wt} . \%$ were added to the $84 \mathrm{wt} . \% \mathrm{NMP}$ and mixed by stirring for $7 \mathrm{~h}$ at $60{ }^{\circ} \mathrm{C}$ and then degassed at room temperature for $18 \mathrm{~h}$. At the same time, in a different place, PVDF with a mass ratio of $16 \mathrm{wt} . \%$ was added to the $84 \mathrm{wt} . \% \mathrm{NMP}$ and then mixed and degassed with the same conditions. The PSf solution was later cast on a gauze support with an initial thickness of $800 \mu \mathrm{m}$ and instantly coating by PVDF with a final thickness of $1,000 \mu \mathrm{m}$. After $30 \mathrm{~min}$ aging at room temperature, the PSf/PVDF membrane matrix was immersed in a coagulation bath at a temperature of $40{ }^{\circ} \mathrm{C}$ for $2 \mathrm{~h}$. Several different stirring time and cast thicknesses were applied are listed in Table 1. The formed PSf/PVDF coated membranes were washed with deionized water to completely remove the residual solvent and pore additive, and then dried in the air at room temperature (ca. $30^{\circ} \mathrm{C}$ ) for $24 \mathrm{~h}$ before characterizations.

Table-1: PSf/PVDF stirring times and cast thicknesses

\begin{tabular}{c|c|c|c}
\hline Membranes & Stirring Time (h) & $\begin{array}{c}\text { PSf Cast Thickness } \\
(\mu \mathrm{m})\end{array}$ & $\begin{array}{c}\text { PVDF Cast } \\
\text { Thickness }(\mu \mathrm{m})\end{array}$ \\
\hline M1 & 7 & 800 & 1,000 \\
\hline M2 & 12 & 800 & 1,000 \\
\hline M3 & 16 & 800 & 1,000 \\
\hline M4 & 20 & 800 & 1,000 \\
\hline M5 & 24 & 800 & 1,000 \\
\hline M6 & 7 & 600 & 800 \\
\hline M7 & 7 & 400 & 600 \\
\hline M8 & 7 & 200 & 400 \\
\hline
\end{tabular}

\section{Membranes Characterization Method FT-IR analysis}

The FT-IR spectra of PSf/PVDF coated membranes were recorded using Nicolet IS10 Thermo Scientific Fourier Transform Infra-Red (FTIR) spectrophotometer in the range of 4,000-400 $\mathrm{cm}^{-1}$. By this, a proper coating of PVDF into PSf membrane matrix was confirmed.

\section{Scanning Electron Microscopy (SEM)}

Surface morphology of PSf/PVDF coated membranes was visualized by scanning electron microscopy, SEM (Zeiss EVO MA10, Germany) with an accelerating voltage of $20.0 \mathrm{kV}$. The membrane samples were dried and then coated with gold for $50 \mathrm{~s}$ before SEM analysis. To obtain the cross-sectional images by SEM, the membrane samples were immersed in liquid nitrogen and fractured.

\section{Porosimetry Analysis}

The overall membrane porosity was measured using the gravimetric method. After measuring the dry weight of the membranes, they were subsequently immersed in DI water for $24 \mathrm{~h}$ to ensure penetration of water into the membrane pores. After removing the excess water from the membrane surface with tissue paper, the wet weight of the membrane was measured. The overall porosity was calculated as follows. ${ }^{6}$ 
RASĀYAN J. Chem.

Vol. 11 | No. 1 | 260 - 279 | January - March | 2018

$$
\text { overall porosity }=\frac{\left(m_{w}-m_{d}\right)}{\rho_{w a t e r} V}
$$

where $m_{w}$ and $m_{d}$ are the weight of the wet and dry membranes, respectively; $p_{\text {wats }}$ is the density of pure water at $25^{\circ} \mathrm{C}$, and $\mathrm{V}$ is the volume of the dry membrane.

The pore radius $\left(r_{\mathrm{sm}}\right)$ was determined using Guerout-Elford-Ferry equation on the basis of water flux and porosity

$$
r_{\mathrm{m}}=\sqrt{\frac{(2.9-1,75 \varepsilon) x 8 \eta \eta Q}{\varepsilon x A x \Delta P}}
$$

Where $\eta$ is the water viscosity $\left(8.9 \times 10^{-4} \mathrm{~Pa} . \mathrm{s}\right) ; \boldsymbol{Q}$ is the volume of the permeate pure water per unit time $\left(\mathrm{m}^{3} / \mathrm{s}\right)$, and $\Delta P$ is the operating pressure $(0.1 \mathrm{MPa})$.

\section{Tensile Strength and Elongation at Break}

Stress-strain measurements of the composite membranes were performed with a strograph instrument (RCT/10KN/AF TOYO SEIKI, Japan). All the testing membranes were dried at $30{ }^{\circ} \mathrm{C}$ overnight before cutting into $15 \mathrm{~mm}$ in width and $100 \mathrm{~mm}$ in length. The clipping distance kept $50 \mathrm{~mm}$. Measurements were carried out at room temperature and a strain rate of $20 \mathrm{~mm} / \mathrm{min}$ was employed. The reported values were the averages of at least three samples. The Young's modulus of the membranes was calculated from the stress-strain data.

\section{Flux Test and Filtration Experiment}

Filtrations were performed in a dead-end filtration cell (self-made), at room temperature and under pressures of 1 bar. ${ }^{28}$ Membrane samples were placed in the module and sealed with O-rings. The active membrane surface area was $0.00246176 \mathrm{~m}^{2} .250 \mathrm{~mL}$ pure water was used as feed. Permeances, expressed in $\left(1 / \mathrm{m}^{2} \mathrm{~h}\right.$ bar), were determined gravimetrically by weighing the collected permeate.

\section{Thermal Resistance}

PSf/PVDF coated membranes were characterized using Perkin Elmer STA-6000 Differential Scanning Calorimetry (DSC)-Thermal Gravimetric Analysis (TGA) with heating temperature from $20 \square \mathrm{C}$ to $700 \square \mathrm{C}$ at a rate of $10 \square \mathrm{C} \mathrm{m^{-1 }}$ to determine membrane thermal stability.

\section{Chemical Resistance}

The acidic resistance of PSf/PVDF coated membranes were evaluated through immersion stage in the sulfuric acid with concentration 80 vol. $\%$. Meanwhile, the alkaline resistance of its membranes was evaluated through immersion in sodium hydroxide with concentration $80 \mathrm{wt} . \%$. The chemical changes before and after immersion in a specific environment were analyzed using Nicolet IS10 Thermo Scientific Fourier Transform Infra-Red (FTIR) spectrophotometer. By this, chemical characteristics changes of the membranes before and after specific immersion were confirmed.

\section{FTIR Analysis}

\section{RESULTS AND DISCUSSION}

FT-IR spectra of polysulfone, polyvinylidene fluoride, and PSf/PVDF coated membrane were measured to confirm proper coating of PVDF in PSf or incorporation of PVDF into PSf membrane matrix. PSf/PVDF membrane (Fig. 1, "c") showed characteristics peaks corresponding to polysulfone at 3000-

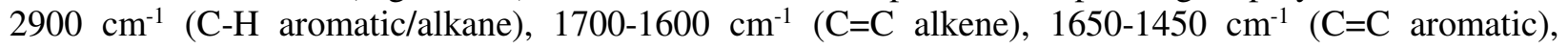
$1170.08 \mathrm{~cm}^{-1}$ (C-O ether) and characteristic peaks corresponding to PVDF at $1170.08-1071.13 \mathrm{~cm}^{-1}(\mathrm{C}-\mathrm{F})$, and $1401.86 \mathrm{~cm}^{-1}(\mathrm{C}-\mathrm{H}$ alkane). These results show that the PSf membrane was successfully modified by PVDF coating. 


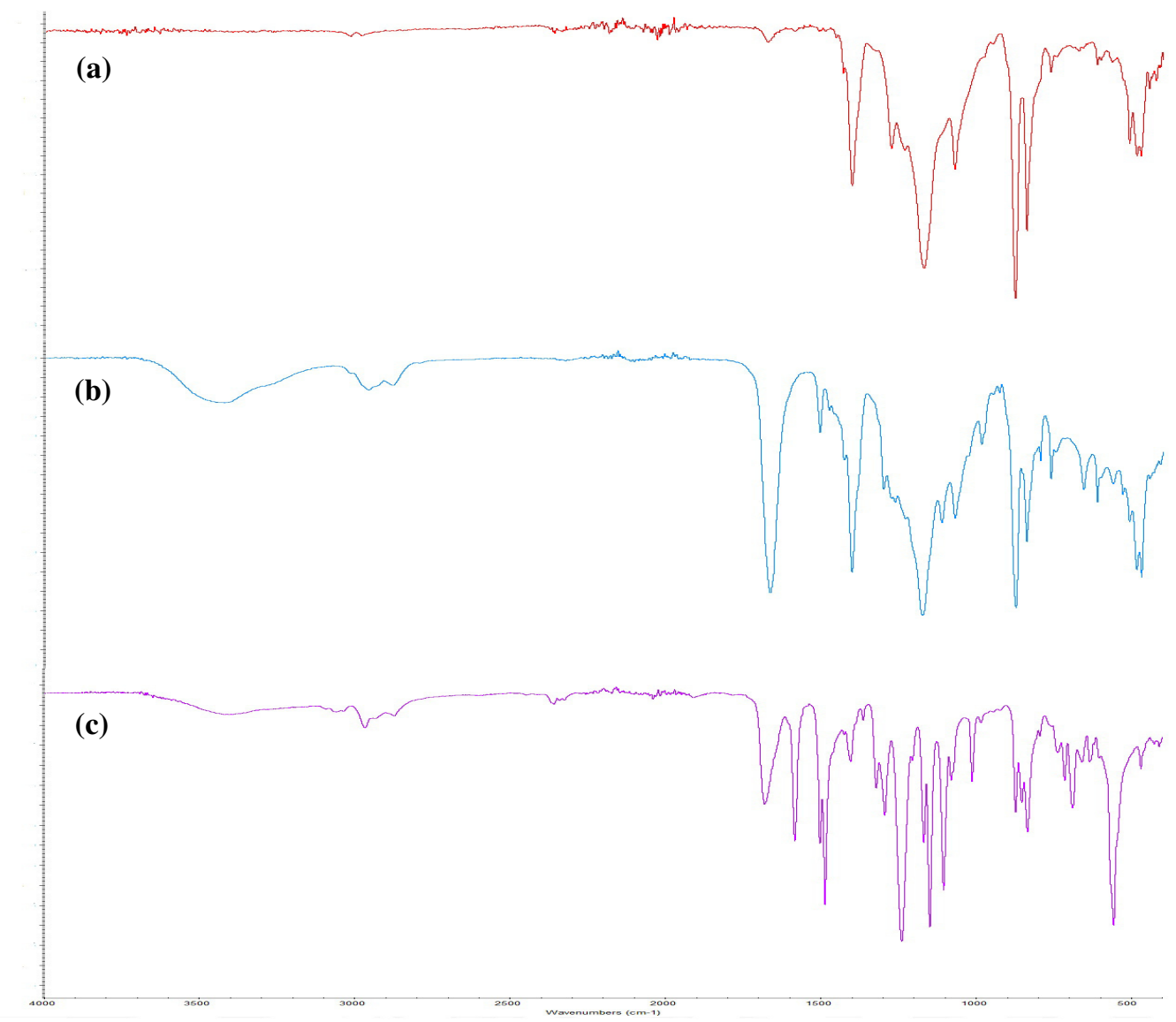

Fig.-1: Infra-red spectra of : (a) PSf membrane; (b) PVDF membrane; (c) PSf/PVDF membrane

\section{Morphology of the Membrane}

In the phase inversion process induced by an immersion-precipitation, a homogeneous polymeric solution is initially demixed into two liquid phases because of exchange of the solvent and nonsolvent. The polymer rich phase forms the solid membrane, while the phase with a lower polymer concentration forms the pores of the membrane. The combination of thermodynamic miscibility of the polymer dope in the coagulation bath and kinetic effect of dope viscosity controls the ultimate membrane structure. ${ }^{35-37}$ The viscosity of both dope solution and coagulation bath played a major role in the formation of final membrane structure. Obviously, the presence of PVDF coating layer in PSf matrix membrane is effective to induce lower size pore formation in a porous layer.

Microscopic studies using SEM images were carried out to determine the effects of the stirring time and cast thickness on the morphology of the prepared membranes. Figs.-2 and 3 present SEM images of the membrane surface and cross-sections which prepared with a different stirring time, respectively.

According to the images in Fig.-3(a) to (d), an increase in stirring time from $7 \mathrm{~h}$ to $20 \mathrm{~h}$ resulted in the greater formation of a more porous structure with reduced pore size. More specifically, in Fig.-3(c) appears significant changes in the pore size of the PSf/PVDF coated membrane. This is not surprising in consideration by the phase inversion kinetics. ${ }^{38-39}$ Stirring process of the casting solution is a mixing process, where nuclei of a polymer-poor phase continue to grow with the continuation of the $\mathrm{NH}_{4} \mathrm{Cl}$ distribution between PSf and PVDF particles. Thus, the rate of the additive distribution affects the membrane structure. Homogenous distribution of $\mathrm{NH}_{4} \mathrm{Cl}$ in the casting solution favors to the formation of a more porous structure with lower pore sizes and minimum macrovoids both on the skin layer and also porous layer, whereas agglomeration of $\mathrm{NH}_{4} \mathrm{Cl}$ often terminates to a denser structure on skin layer with 
RASĀYAN J. Chem.

Vol. 11 | No. 1 | 260 - 279 | January - March | 2018

bigger pore sizes and macrovoids on the porous layer. Note that the high viscosity of the membrane dope solution prepared by the stirring time for 24 hours has resulted in the inability of the PSf/PVDF membrane to be cast.
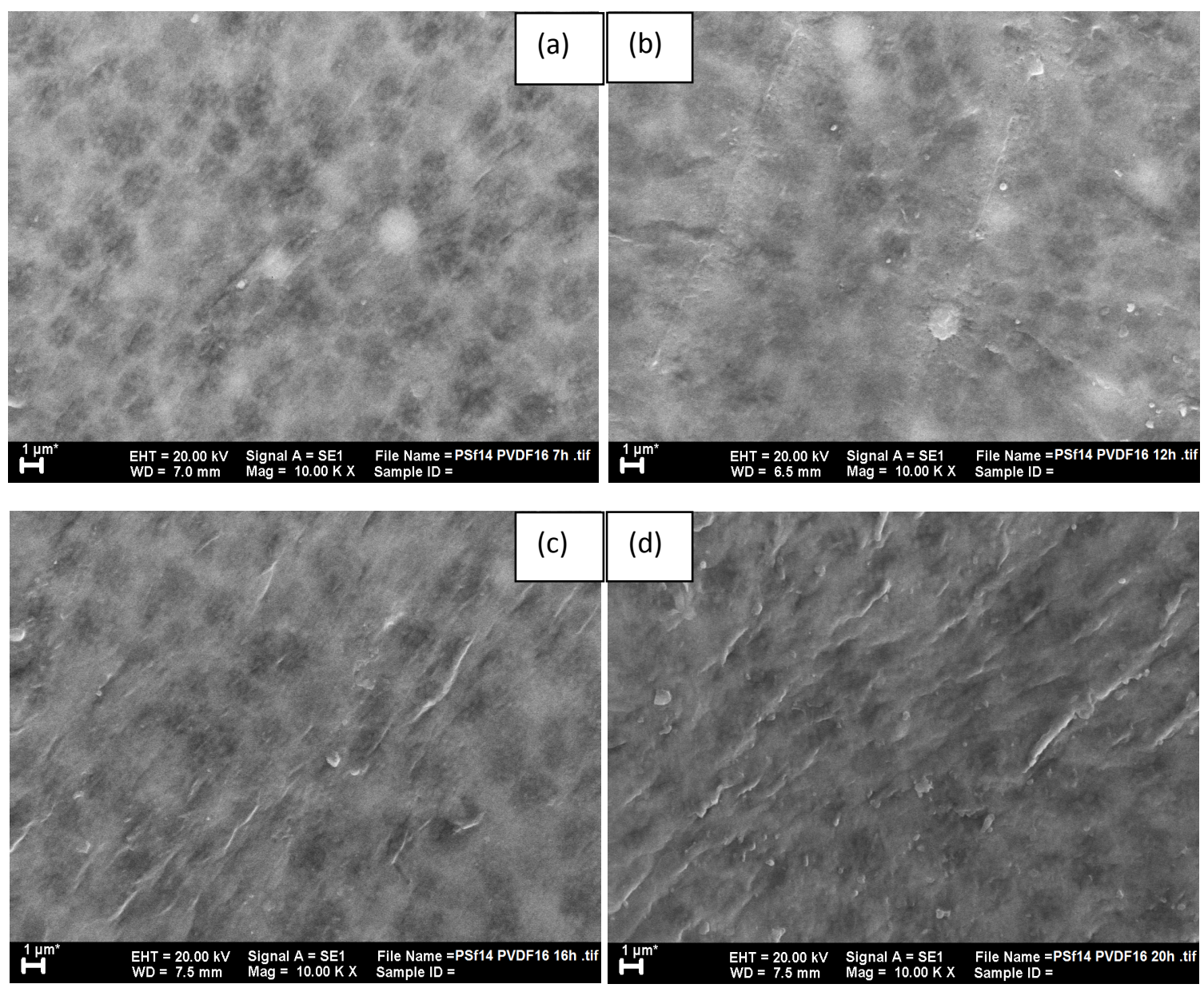

Fig.-2: SEM images of membranes: (a), (b), (c), and d) are the surface morphology of M1, M2, M3, and M4 respectively

To confirm the validity of the above-mentioned rule on these PSf/PVDF coated membranes, porosity and pore size of the prepared membranes with different stirring times were measured and the results are shown in Fig.-4. It can be seen that the elevation in stirring time from $7 \mathrm{~h}$ to $20 \mathrm{~h}$ indeed results in an obvious increase in porosity and decrease in pore size, which is also observed in Fig.-3(a) to (d) (the cross-sectional images). Moreover, Fig.-3(a) to (d) exhibits a typical asymmetric structure of the membranes M3 and M4, which comprises a dense thin top layer and porous sub layer with reduced pores size. Obviously, a pore size decrease in the fully developed pores in sub-layer with the elevated stirring times can be observed. For example, the membrane sub-layer (in Fig.-3(c) and (d)) has an asymmetry structure dominated by the presence of finger pore within the polymer matrix, while the sponge-like structure seems less noticeable compared to that of other images of membranes. In fact, the final structure depends on the homogenous mixing in the preparation process.

Similar finding was reported that the pore size gradually decreased with an elevation of stirring times and a decline in casting thicknesses. ${ }^{40}$ As evaluated above, the stirring time and casting thickness play an important role in the membrane formation via the phase inversion method. However, level of cast thickness of polymer solution seems to be large for the control and regulation of membrane morphology. Effect of the casting thickness on the morphology and structure of the prepared membranes was 
RASĀYAN J. Chem.

Vol. 11 | No. 1 | 260 - 279 | January - March | 2018

investigated and the results are shown in Figs.-5(a) to (d), a decrease in cast thickness from $1.0 \mathrm{~mm}$ to 0.4 $\mathrm{mm}$ results in the greater formation of a higher porosity and smaller pore sizes in the skin layer and lower thickness of the porous layer in the PSf/PVDF coated membrane.
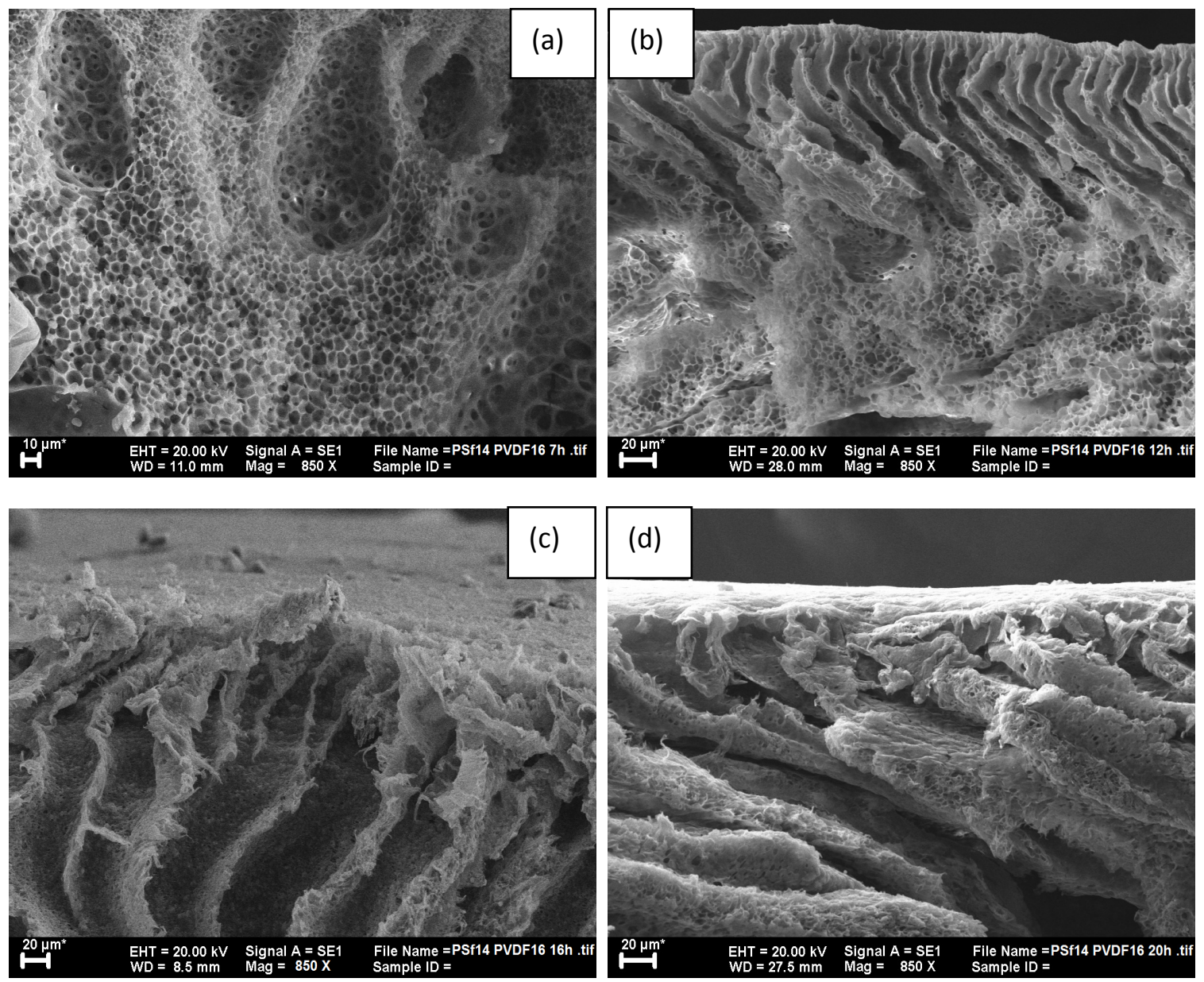

Fig.-3: SEM images of membranes: (a),(b), (c), and (d) is the cross-section morphology of M1, M2, M3, and M4 respectively

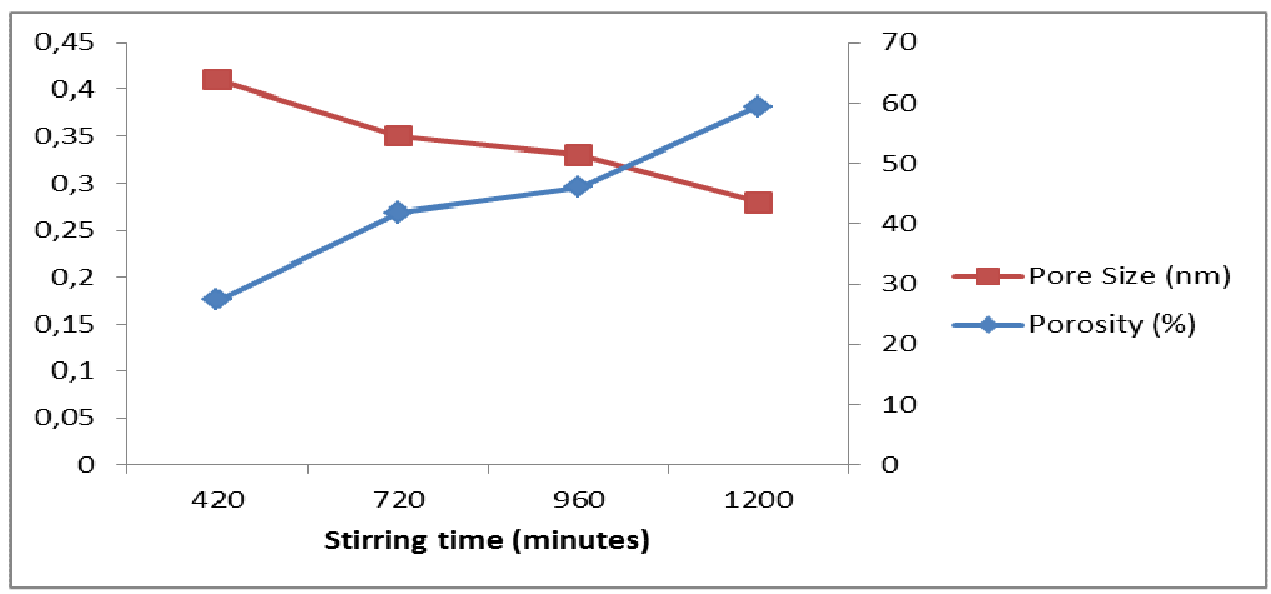

Fig.-4: The porosity and pore size of the PSf/PVDF membrane with different stirring times 
RASĀYAN J. Chem.

Vol. 11 | No. 1 | 260 - 279 | January - March | 2018

This is consistent with those reported by the earlier researcher. ${ }^{28}$ Casting process of the membrane solution is a preparation process of the membrane, where nuclei of polymer-rich phase continue to grow with the continuation of the solvent until the polymer concentration at their thickness limits becomes too high, and suppress the growth of polymer-poor phase. In the other words, the growth of polymer-poor phase (pore) will tend to be depressed along with the depressed growth of polymer-rich phase (matrix) due to the influence of external pressure by the thickness of cast applied to the casting knife. Thus, the rate of external pressure affect the membrane structure. Large external pressure on the application of 0.4 $\mathrm{mm}$ in the casting solution favors to the formation of more porous structure with a lower pore sizes and minimum macrovoids both on the skin layer and also porous layer, whereas application of higher casting thickness often terminates to the formation of less porous structure with a higher pore sizes and maximum macrovoids.
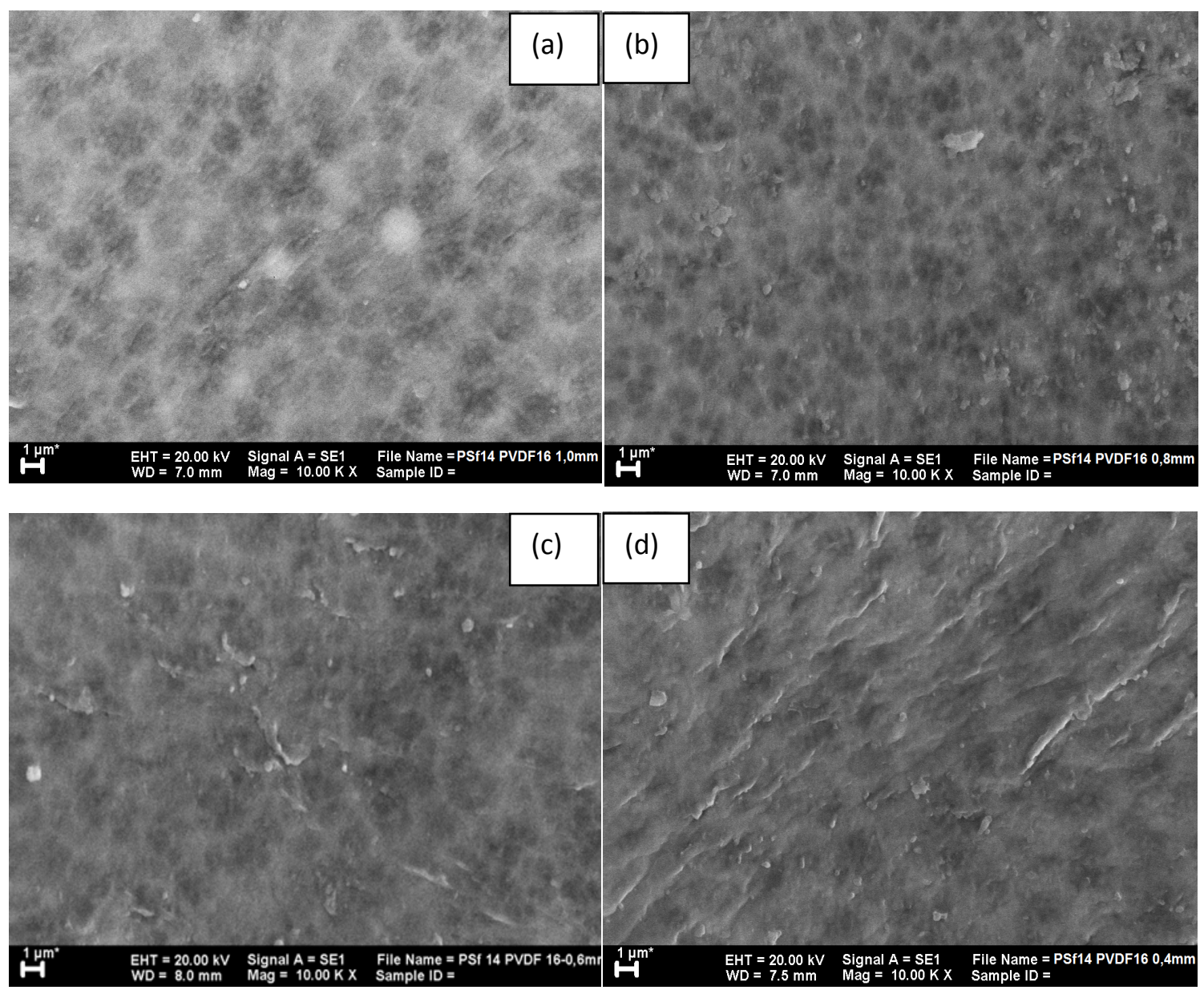

Fig.-5: SEM images of membranes: (a), (b), (c), and (d) is the surface morphology of M1, M6, M7, and M8 respectively

Same with the previous section, to confirm the validity of the above-mentioned rule on these PSf/PVDF coated membranes, porosity and pore size of the prepared membranes with a different casting thickness was measured and the results are shown in Fig.-7. It can be seen that the decline in casting thickness from $1.0 \mathrm{~mm}$ to $0.4 \mathrm{~mm}$ indeed results in an obvious increase in porosity and decrease in pore size, which is also observed in Fig.-6(a) to (d) (the cross-sectional images). Moreover, Fig.-6(a) to (d) also exhibits a same typical asymmetric structure of the membranes, which comprises a dense thin top layer and porous sub layer with finger pores like macrovoids. Obviously, a pore size decrease in the fully developed pores 
in porous-layer with the decreased casting thickness can be observed. For example, the membrane porous layer (in Fig.-7d) is completely filled by a fingerlike pore structure that composes a polymer matrix with a very tight sponge-like structure that is unobserved compared to other membrane images. In fact, the final structure depends on the external pressure resulted by casting thickness in the preparation process.
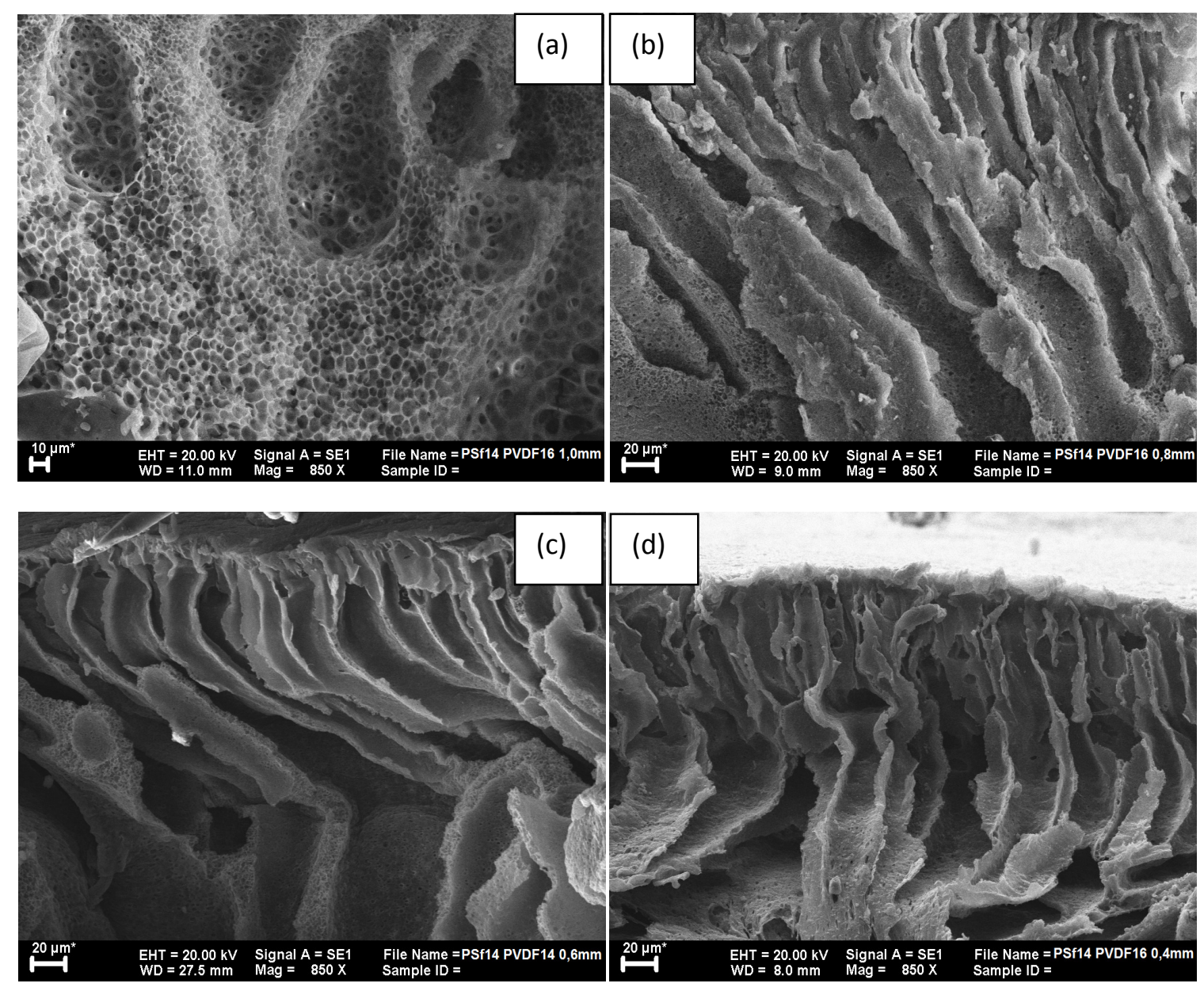

Fig.-6: SEM images of membranes: (a), (b), (c), and (d) is the cross-section morphology of M1, M6, M7, and M8 respectively

A stirring time and casting thickness are commonly used as variable of membrane preparation conditions to control the homogenous mixing and external pressure rate for membrane fabrication, and its effects on the morphology and separation performance of the membranes have been widely investigated in previous studies. ${ }^{28}$ However, research on the effect of stirring time and casting thickness on the properties of this novel PSf/PVDF ultrafiltration membrane with surface modifications are lacking. Therefore, it is necessary to investigate the above-mentioned effect using $7 \mathrm{~h}-20 \mathrm{~h}$ stirring times and $0.4 \mathrm{~mm}-1.0 \mathrm{~mm}$ casting thickness, and the results are shown in Figs.-2(a), (b), (c), (d) and 3(a), (b), (c), (d) for a different stirring times also in Figs.-5(a), (b), (c), (d) and 6(a), (b), (c), (d) for a different casting thickness. As the stirring time of casting solution increases from $7 \mathrm{~h}$ to $16 \mathrm{~h}$, the pores on the membrane surface are obviously smaller in size but are not properly formed at the magnification used. However, when the stirring time is sufficiently high $(20 \mathrm{~h})$, a relatively uniform surface with more porous structure can be observed and even pores on the membrane surface with $20 \mathrm{~h}$ stirring times are least and smallest than those of membrane surface with $7 \mathrm{~h}$ stirring times, which indicates the serious pore shrinkage. While when the casting thickness decreases from $1.0 \mathrm{~mm}$ to $0.6 \mathrm{~mm}$, the pores on the membrane surface are not 
obviously smaller in size but are also not properly formed at the magnification used. However, when the casting thickness is sufficiently low $(0.4 \mathrm{~mm})$, a relatively uniform surface with more porous structure can be observed and even pores on it surface is least and smallest than those of membrane surface with 1.0 $\mathrm{mm}$ casting thickness, which also indicates the significant pore shrinkage.

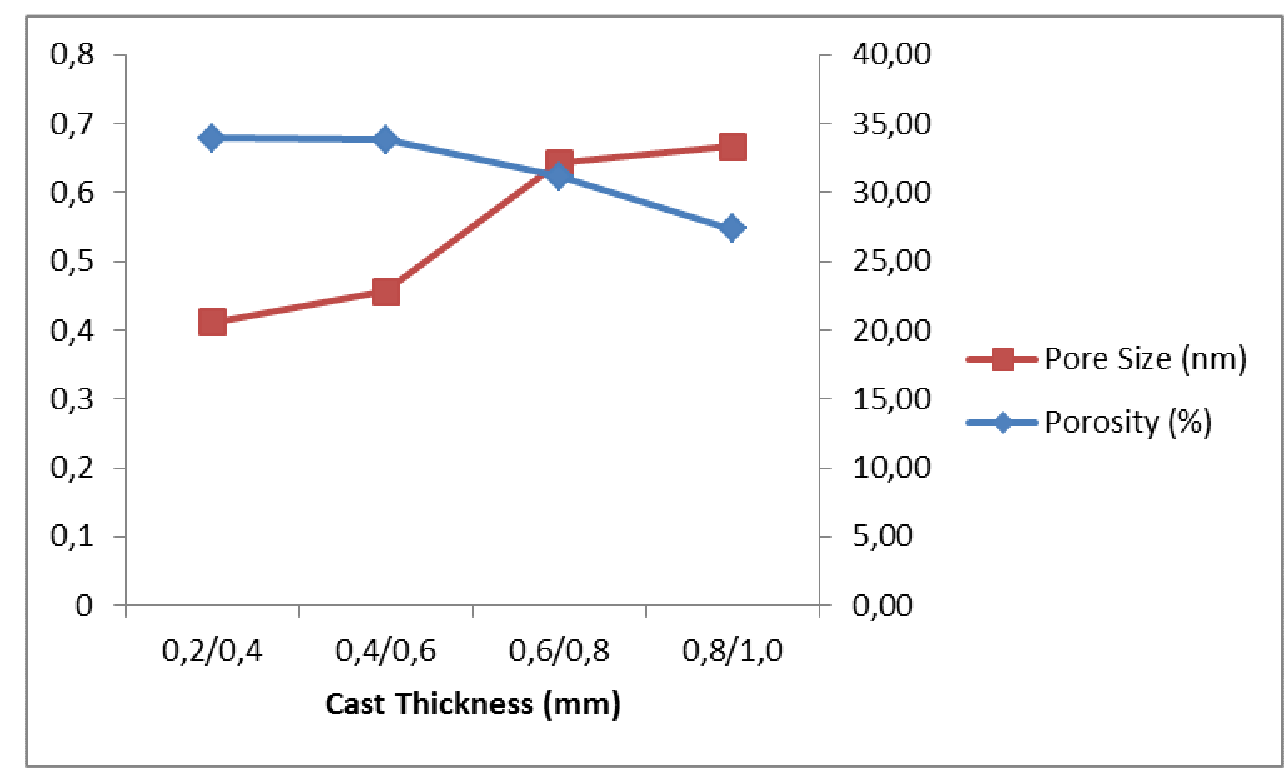

Fig.-7: The porosity and pore size of the PSf/PVDF membrane with different cast thicknesses

From the results obtained, it is interesting to note that the preparation time required as a consequence of the application of the stirring conditions is remarkably longer than that of the casting condition for obtaining the equivalent effect on the control and regulation of membrane morphology. Therefore, casting condition shows a greater probability as a key parameter for the manufacture of high-performance PSf/PVDF ultrafiltration membrane.

\section{Tensile Strength and Elongation at Break}

To evaluate the mechanical strength of the prepared membranes, Young's modulus analysis was performed. Fig.-8a shows Young's modulus of the PSf/PVDF coated membranes with different stirring times. The Young's modulus of PSf/PVDF membranes with stirring times of $7 \mathrm{~h}, 12 \mathrm{~h}, 16 \mathrm{~h}$, and $20 \mathrm{~h}$ corresponded to 4,$561 ; 5,882 ; 6,330$; and 7,887 N/m², respectively. The PSf/PVDF membranes Young's modulus was increased with increasing stirring time. The results indicated that the homogenous stirring has some effect on Young's modulus of the prepared membrane. Homogenous distribution of $\mathrm{NH}_{4} \mathrm{Cl}$ in the casting solution favors to the formation of a more porous structure with lower pore sizes and minimum macrovoids both on the skin layer and also porous layer. Thus, increased stirring time has increased Young's modulus of PSf/PVDF membrane.

A different result has been generated on a membrane made with a decrease in cast thickness. Fig.-8(b) shows Young's modulus of the PSf/PVDF coated membranes with different casting thicknesses. The Young's modulus of PSf/PVDF membranes with casting thicknesses of $1.0 \mathrm{~mm}, 0.8 \mathrm{~mm}, 0.6 \mathrm{~mm}$, and 0.4 mm corresponded to 4,561; 1,538; 968; and $500 \mathrm{~N} / \mathrm{m}^{2}$, respectively. The PSf/PVDF membranes Young's modulus was increased with increasing casting thickness. This phenomenon is not in line with the results of surface and cross-section morphology analysis of PSf/PVDF coated membrane which states the increase of porosity and the decrease of pore size along with the decrease of membrane cast thickness. Although the increase in porosity and the decrease of pore size at the same time theoretically will lead to an increase in mechanical strength, however, a decrease in the porous layer or sub layer thickness of the membrane at the same time, has resulted in a significant decrease in mechanical strength of the 
membrane. These results indicate that changes in the porous layer or sub layer thickness have a more significant effect on mechanical strength compared to the increased porosity and the decreased pore size of the tested membrane.
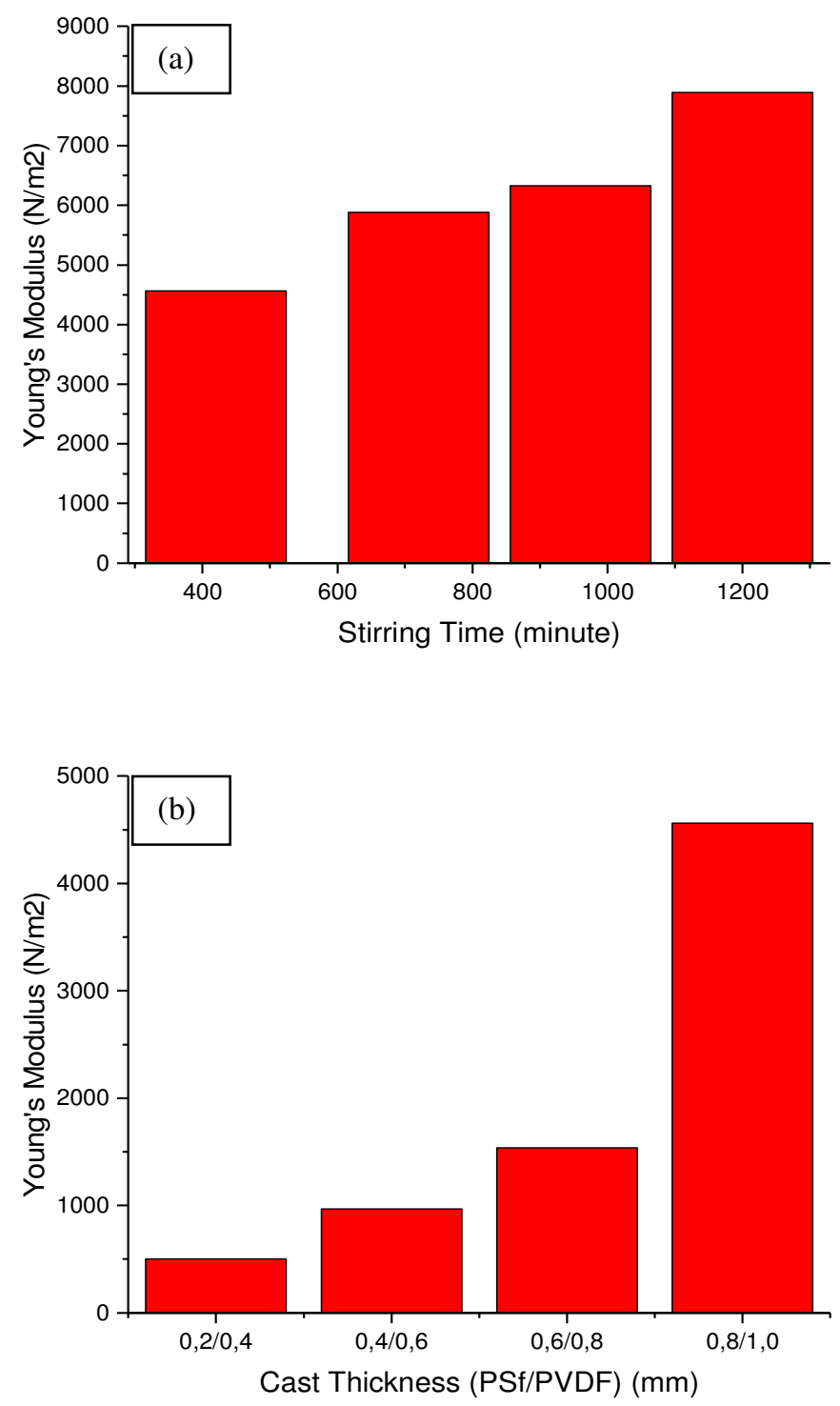

Fig.-8: Young's modulus of the PSf/PVDF membrane with different in (a) stirring times and (b) cast thicknesses

\section{Permeability}

Prior to filtration experiments, pure water flux of the prepared membranes was determined to roughly study the permeability property of PSf/PVDF membranes. The obtained results are presented each in Fig.9(a) for membranes with a different stirring time and Fig.-9(b) for membranes with a different casting thickness. As observed, the prepared membranes are more permeable when the stirring time decreases from $20 \mathrm{~h}$ to $16 \mathrm{~h}, 12 \mathrm{~h}$, and $7 \mathrm{~h}$, with the corresponding values of 2,229;2,856;3,226; and 3,515 L/m $\mathrm{m}^{2} \mathrm{~h}$ bar, respectively. These measurements confirm the trends observed in the SEM images (in Figs.-3 and 4). An increase in stirring time leads to the greater formation of a more porous structure with smaller pore sizes and macrovoids, which consequently improves the main resistance against the water permeation, 
particularly at the higher stirring time. Therefore, the membrane prepared at stirring time of $7 \mathrm{~h}$ exhibits the highest pure water permeability.

In line to the above conditions, the prepared membranes are more permeable when the casting thickness decreases from $1.0 \mathrm{~mm}$ to $0.8 \mathrm{~mm}, 0.6 \mathrm{~mm}$, and $0.4 \mathrm{~mm}$, with the corresponding values of 3,515; 8,569; 11,425 ; and $22,850 \mathrm{~L} / \mathrm{m}^{2} \mathrm{~h}$ bar, respectively. An increase in casting thickness leads to the greater formation of less porous structure but with bigger pore size and higher porous layer thickness which dominantly improves the main resistance against the water permeation, particularly at highest casting thickness. Therefore, the membrane prepared at casting thickness of $0.4 \mathrm{~mm}$ exhibits the highest pure water permeability.

It indicates that the permeability property of membranes depends on morphology. However, morphology is not the sole determinant of membrane permeability. In the other words, the combined effects of morphology and hydrophilicity together are of importance to the property of membranes. Therefore, it is important to learn more about the dominance of morphological influence compared to the hydrophilic properties against membrane permeability by water contact angle analysis of the prepared membrane.
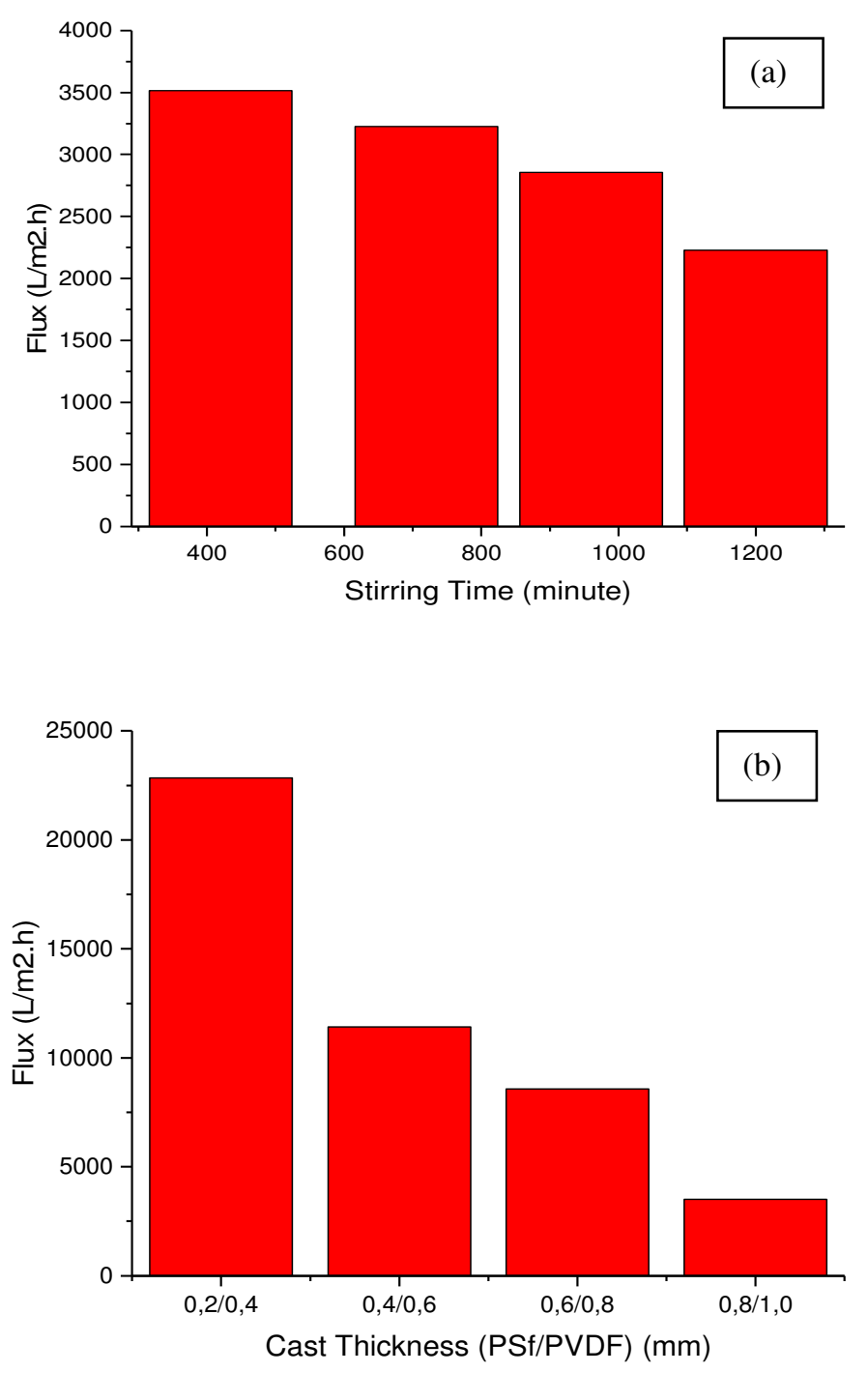

Fig.-9: Pure water flux of the PSf/PVDF membrane with different in (a) stirring times and (b) cast thicknesses 


\section{Thermal Resistance}

To determine thermal stability, a thermal resistance analysis of PSf/PVDF membrane using DSC-TGA was performed. According to Fig.-10, the thermogravimetric analysis results showed the decomposition of PSf and PVDF in several steps. Decomposition is characterized by a reduction in membrane mass during an increase in temperature. The first and second mass reductions each occurred respectively over the temperature range of 50-220 ${ }^{\circ} \mathrm{C}$ which associated with the release of water molecules in the vapor form and in the range of $220-320{ }^{\circ} \mathrm{C}$ in relation to the release of NMP adsorbed on the surface and internal pore of the membrane. The third mass reduction occurred in the temperature range of 320-400 ${ }^{\circ} \mathrm{C}$. This is thought to be the mass reduction associated with PVDF decomposition. This result is in accordance with the earlier publication which reports PVDF decomposition at a temperature of about 375 ${ }^{\circ} \mathrm{C} .{ }^{28}$ While the fourth mass reduction occurred at a temperature of about $400-460{ }^{\circ} \mathrm{C}$, caused by the decomposition of PSf.
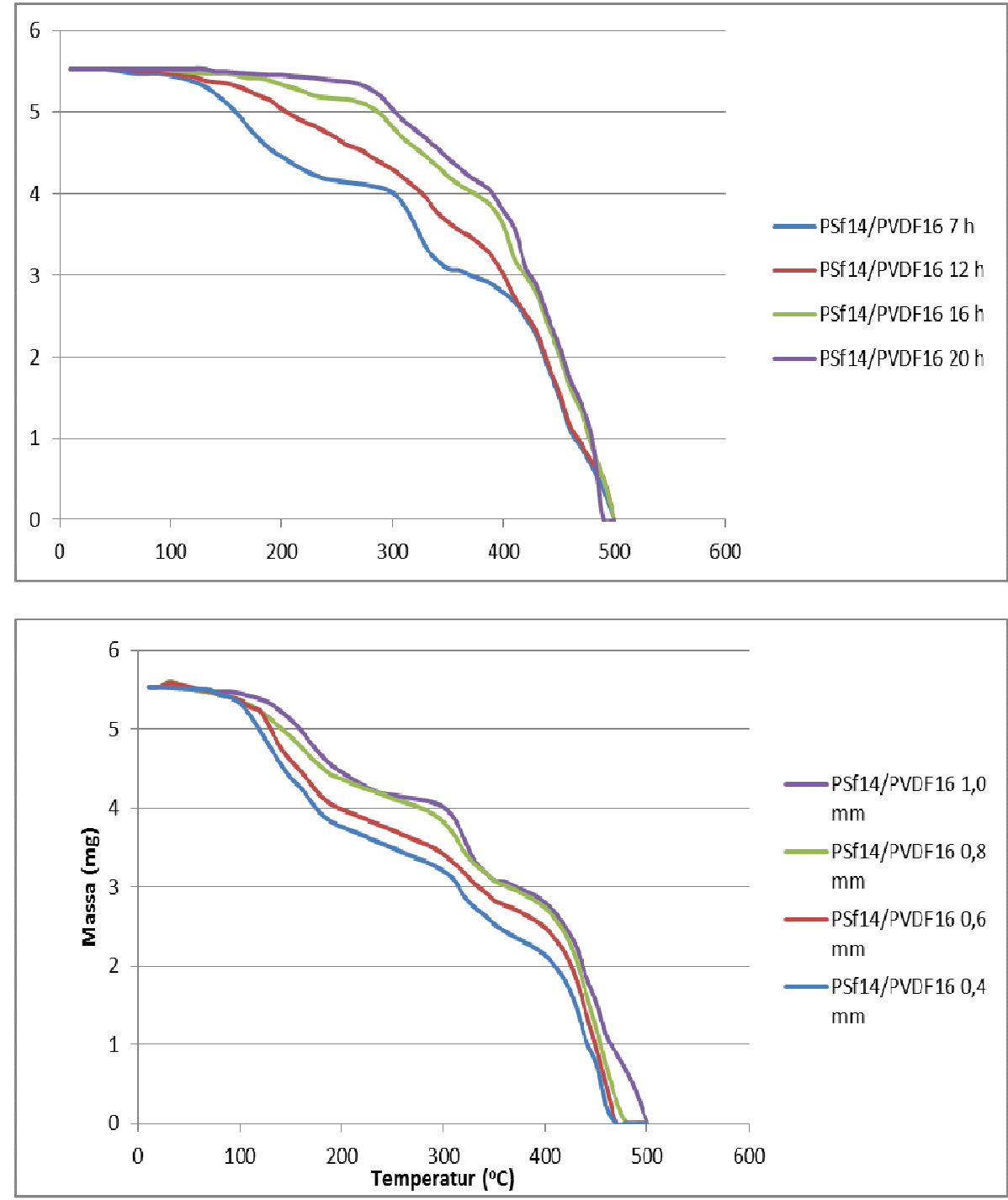

Fig.-10: Thermal resistance of the PSf/PVDF membrane with different in a) stirring times and b) cast thicknesses

Increased stirring time will increase the homogeneity of the dope solution and induce an increase in the density of the membrane constituent particles which leads to an increase in the bonding energy and heat 
RASĀYAN J. Chem.

Vol. 11 | No. 1 |260 - 279 | January - March | 2018

resistance of the membrane. Such conditions will cause delays in the membrane decomposition process. However, based on the thermogram shown in Fig.-10a, no significant changes in thermal resistance of the $\mathrm{PSf} / \mathrm{PVDF}$ membrane with stirring time variation. The condition is triggered by no significant change in the thickness of the porous layer or sub layer along with the application of increased stirring time.

Contrary to this, an increase in the thickness of the membrane casting has precisely induced a decrease in particle density and bonding energies between the membrane constituent particles. However, at the same time, there has been an increase in a porous layer thickness of the membrane. This leads to increased thermal resistance and delay in the PSF/PVDF coated membrane decomposition process even though the bond energy between the membrane constituent particles decreases. Thus, the increased porous layer membrane thickness has a more significant effect on membrane's thermal stability than the decrease in the bonding energy of the constituent particles. Based on the thermogram shown in Fig. 10 (b), it is known that an increase in casting thickness from $0.4 \mathrm{~mm}$ to $1.0 \mathrm{~mm}$ has increased the thermal resistance of PSf/PVDF coated membrane from $460{ }^{\circ} \mathrm{C}$ to $500{ }^{\circ} \mathrm{C}$.

\section{Chemical Resistance}

Functional groups analysis of PSF/PVDF coated membrane using FTIR (Fig.-11 (a) and 12 (a)) showed lower resistances of PSf / PVDF coated membrane in the alkaline environment than in the acidic. This is evident from the loss of a large number of PSf and PVDF characteristics peak after immersion in sodium chloride $(\mathrm{NaCl})$ for 24 hours. In contrast, the higher resistance of PSf/PVDF coated membrane in the acidic environment is evidenced by the absence of significant losses detectability of PSf and PVDF characteristics peak after immersion in the sulfuric acid. The effect of acidic environment on the chemical resistance of PSf/PVDF coated membrane increases with the increase of stirring time and casting thickness applied in the membrane preparation process. Table 2-7 shows the characteristics peak of PSf and PVDF obtained from the functional group analysis results of the PSf/PVDF coated membrane with varying stirring time using FTIR

Table-2: Infra red spectrum of PSf/PVDF coated membrane with varying stirring time (before immersion)

\begin{tabular}{|c|c|c|c|c|c|c|}
\hline \multirow{2}{*}{ No } & \multirow{2}{*}{$\begin{array}{c}\text { Wavenumber } \\
\left(\mathrm{cm}^{-1}\right)\end{array}$} & \multicolumn{5}{|c|}{ Stirring Time (h) } \\
\hline & & & & 12 & 16 & 20 \\
\hline 1 & $\begin{array}{l}3600-3200 \\
\text { (OH bonded) }\end{array}$ & 3275.73 & & 3392.83 & & 3412.23 \\
\hline 2 & $\begin{array}{l}3000-2850 \\
\text { (C-H alkane) }\end{array}$ & 2965.49 & & 2966.75 & 2965.68 & 2966.86 \\
\hline 3 & $\begin{array}{l}1820-1670 \\
(\mathrm{C}=\mathrm{O})\end{array}$ & 1675.65 & & 1678.08 & 1674.77 & 1682.17 \\
\hline 4 & $\begin{array}{l}1600-1400 \\
(\mathrm{C}=\mathrm{C} \text { aromatic })\end{array}$ & $\begin{array}{l}\text { 1581.88; } \\
\text { 1485.24; }\end{array}$ & $\begin{array}{l}1502.58 ; \\
104.60\end{array}$ & $\begin{array}{l}1583.76 ; 1502.94 \\
1486.64 ; 1404.57\end{array}$ & $\begin{array}{l}\text { 1581.71; 1501.95; } \\
\text { 1485.08; 1404.18 }\end{array}$ & $\begin{array}{l}\text { 1583.59; 1502.87; } \\
1486.61 ; 1405.49\end{array}$ \\
\hline 5 & $\begin{array}{l}1400-1000 \\
(\mathrm{C}-\mathrm{F})\end{array}$ & $\begin{array}{l}1363.75 ; \\
1292.91 ; \\
1167.04 ; \\
1102.10 ; \\
1012.65\end{array}$ & $\begin{array}{l}\text { 1320.29; } \\
1234.79 \\
1146.56 \\
1079.76\end{array}$ & $\begin{array}{ll}1363.83 ; & 1321.77 \\
1293.93 ; & 1238.45 \\
1168.55 ; & 1148.76 \\
1104.47 ; & 1080.54 \\
1013.33 & \end{array}$ & $\begin{array}{ll}1363.73 ; & 1320.58 ; \\
1293.00 ; & 1234.19 ; \\
1167.76 ; & 1146.62 ; \\
1102.60 ; & 1080.10 ; \\
1012.69\end{array}$ & $\begin{array}{l}\text { 1363.80; 1321.71; } \\
\text { 1293.71; 1237.48; } \\
\text { 1168.48; 1148.55; } \\
\text { 1104.33; 1080.40; } \\
1013.23\end{array}$ \\
\hline 6 & $\begin{array}{l}1300-1000 \\
\text { (C-O ether) }\end{array}$ & $\begin{array}{l}\text { 1292.91; } \\
\text { 1167.04; } \\
\text { 1102.10; } \\
1012.65\end{array}$ & $\begin{array}{l}1234.79 \\
\text { 1146.56; } \\
\text { 1079.76; }\end{array}$ & $\begin{array}{ll}1293.93 ; & 1238.45 \\
1168.55 ; & 1148.76 \\
1104.47 ; & 1080.54 \\
1013.33 & \end{array}$ & $\begin{array}{ll}1293.00 ; & 1234.19 ; \\
1167.76 ; & 1146.62 ; \\
1102.60 ; & 1080.10 ; \\
1012.69 & \end{array}$ & $\begin{array}{l}\text { 1293.71; 1237.48; } \\
\text { 1168.48; 1148.55; } \\
\text { 1104.33; 1080.40; } \\
\text { 1013.23 }\end{array}$ \\
\hline
\end{tabular}

Table-3: Infra red spectrum of PSf/PVDF coated membrane with varying stirring time after sulfuric acid immersion

\begin{tabular}{|c|c|c|c|c|c|}
\hline \multirow{2}{*}{ No } & \multirow{2}{*}{$\begin{array}{c}\text { Wavenumber } \\
\left(\mathrm{cm}^{-1}\right)\end{array}$} & \multicolumn{4}{|c|}{ Stirring Time $(\mathrm{h})$} \\
\hline & & 7 & 12 & 16 & 20 \\
\hline 1 & $\begin{array}{l}3600-3200 \\
\text { (OH bonded) }\end{array}$ & & 3379.42 & & \\
\hline 2 & $3100-3010$ & 3017.21 & 3059.63 & & \\
\hline
\end{tabular}


RASĀYAN J. Chem.

Vol. 11 | No. 1 |260 - 279 | January - March | 2018

\begin{tabular}{|c|c|c|c|c|c|}
\hline & (=C-H alkene) & & & & \\
\hline 3 & $\begin{array}{l}3000-2850 \\
\text { (C-H alkane) }\end{array}$ & & 2964.86 & 2966.17 & 2965.20 \\
\hline 4 & $\begin{array}{l}1820-1670 \\
(\mathrm{C}=\mathrm{O})\end{array}$ & $\begin{array}{l}1763.82 ; \quad 1721.30 \\
1690.80 ; 1678.32\end{array}$ & 1677.38 & & 1685.48 \\
\hline 5 & $\begin{array}{l}1680-1620 \\
(\mathrm{C}=\mathrm{C} \text { alkene })\end{array}$ & $\begin{array}{ll}1649.30 ; & 1641.45 ; \\
1630.69 & \\
\end{array}$ & 1677.38 & & \\
\hline 6 & $\begin{array}{l}1600-1400 \\
(\mathrm{C}=\mathrm{C} \text { aromatic })\end{array}$ & $\begin{array}{l}\text { 1510.86;1501.85; } \\
1460.95\end{array}$ & $\begin{array}{l}1581.38 ; 1503.69 \\
1485.61 ; 1407.63\end{array}$ & $\begin{array}{l}\text { 1582.60; 1502.92; } \\
1485.90 ; 1407.12\end{array}$ & $\begin{array}{l}\text { 1582.33; 1503.14; } \\
1485.91 ; 1404.03\end{array}$ \\
\hline 7 & $\begin{array}{l}1480-1350 \\
\text { (-C-H alkane) }\end{array}$ & 1460.95 & 1407.63 & 1407.12 & 1404.03 \\
\hline 8 & $\begin{array}{l}1400-1000 \\
(\mathrm{C}-\mathrm{F})\end{array}$ & $\begin{array}{l}1400.67 ; \quad 1274.63 ; \\
1162.83 ; 1069.64\end{array}$ & $\begin{array}{l}1291.15 ; 1232.28 \\
1166.90 ; \\
1102.34\end{array}$ & $\begin{array}{l}\text { 1292.46;1233.96; } \\
1167.28 ; 1146.30 ; \\
1102.84 ; 1045.53 \\
1012.31\end{array}$ & $\begin{array}{l}\text { 1290.68; 1231.29; } \\
\text { 1166.52; 1146.03; } \\
\text { 1102.67; 1071.27; } \\
1012.49\end{array}$ \\
\hline 9 & $\begin{array}{l}1300-1000 \\
\text { (C-O ether) }\end{array}$ & $\begin{array}{l}\text { 1274.63; } 1162.83 ; \\
1069.64\end{array}$ & $\begin{array}{l}1291.15 ; 1232.28 \\
1166.90 ; \\
1102.34\end{array}$ & $\begin{array}{l}\text { 1292.46;1233.96; } \\
1167.28 ; 1146.30 ; \\
1102.84 ; 1045.53 \\
1012.31\end{array}$ & $\begin{array}{l}\text { 1290.68; 1231.29; } \\
\text { 1166.52; 1146.03; } \\
\text { 1102.67; 1071.27; } \\
\text { 1012.49 }\end{array}$ \\
\hline
\end{tabular}

Table-4: Infra red spectrum of PSf/PVDF coated membrane with varying stirring time after sodium chloride

\begin{tabular}{|c|c|c|c|c|c|}
\hline \multirow{2}{*}{ No } & \multirow{2}{*}{$\begin{array}{c}\text { Wavenumber } \\
\left(\mathrm{cm}^{-1}\right)\end{array}$} & \multicolumn{4}{|c|}{ Stirring Time (h) } \\
\hline & & 7 & 12 & 16 & 20 \\
\hline 1 & $\begin{array}{l}3600-3200 \\
(\mathrm{OH} \text { bonded) }\end{array}$ & 3350.39 & & 3456.20 & \\
\hline 2 & $\begin{array}{l}3000-2850 \\
(\mathrm{C}-\mathrm{H} \text { alkane })\end{array}$ & & 2966.29 & & $2919.15 ; 2847.49$ \\
\hline 3 & $\begin{array}{l}1820-1670 \\
(\mathrm{C}=\mathrm{O})\end{array}$ & & 1679.57 & 1677.33 & \\
\hline 4 & $\begin{array}{l}1680-1620 \\
(\mathrm{C}=\mathrm{C} \text { alkene })\end{array}$ & & 1679.57 & 1677.33 & \\
\hline 5 & $\begin{array}{l}1600-1400 \\
(\mathrm{C}=\mathrm{C} \text { aromatic })\end{array}$ & 1604.49 & $\begin{array}{l}1583.78 ; 1502.13 ; \\
1486.00 ; 1407.16\end{array}$ & 1448.55 & $1559.84 ; 1432.21$ \\
\hline 6 & $\begin{array}{l}1400-1000 \\
(\mathrm{C}-\mathrm{F})\end{array}$ & $1401.72 ; 1131.72$ & $\begin{array}{l}\text { 1322.38; 1293.73; } \\
\text { 1237.85;1168.52; } \\
\text { 1148.62; } \\
\text { 1104.36;1080.26; } \\
\text { 1013.25 }\end{array}$ & 1057.13 & $\begin{array}{l}\text { 1396.14; } 1275.58 ; \\
1172.64 ; 1069.01\end{array}$ \\
\hline 7 & $\begin{array}{l}1300-1000 \\
\text { (C-O ether) }\end{array}$ & 1131.72 & $\begin{array}{l}\text { 1293.73; } \\
\text { 1237.85;1168.52; } \\
\text { 1148.62; } \\
\text { 1104.36;1080.26; } \\
1013.25\end{array}$ & 1057.13 & $\begin{array}{l}\text { 1275.58; 1172.64; } \\
1069.01\end{array}$ \\
\hline
\end{tabular}

Chemical resistance test of the PSf/PVDF coated membrane in alkaline environment showed that $\mathrm{PSf} / \mathrm{PVDF}$ coated membrane did not have good resistance to alkaline environment. This is evident from the detection of physical changes occurring in PSf/PVDF coated membranes that gradually become brown and finally black after immersion in sodium hydroxide for 24 hours. The resulting black color will darken as the sodium hydroxide concentration increases.

Figure-11(c) and 12(c) show a significant loss in the peak at wave numbers of $1400-1000 \mathrm{~cm}^{-1}$. This condition indicates that the treatment in the alkaline environment has caused membrane dehydrofluorination, loss of HF functional groups. Thus, the gradual discoloration of the membrane from 
white gradually becomes brown and then black after immersion in an alkaline solution occurs due to the dehydrofluorination of the PVDF compound in the composite structure.

The infra-red spectra data in Fig.-11(c) and 12(c) showed a lower chemical resistance of PSf/PVDF membranes in the alkaline environment more affected by the weakness of the PVDF polymer in base solutions. This is evident from the high quantity lost of C-F functional groups peak characteristic after immersion in $\mathrm{NaOH}$. More specifically, increased stirring time and casting thickness are known to have an effect on acid and alkaline resistance of PSf/PVDF coated membrane. The increasing density resulting in increased bond energy between membrane particles along with increasing stirring time and casting thickness has resulted in better PSf/PVDF coated membrane resistance to acid and alkaline environments.

Table-5: Infra red spectrum of PSf/PVDF coated membrane with varying casting thickness (before immersion)

\begin{tabular}{|c|c|c|c|c|c|}
\hline \multirow{2}{*}{ No } & \multirow{2}{*}{$\begin{array}{l}\text { Wavenumber } \\
\left(\mathrm{cm}^{-1}\right)\end{array}$} & \multicolumn{4}{|c|}{ Casting Thickness (mm) } \\
\hline & & 0.4 & 0.6 & 0.8 & 1.0 \\
\hline 1 & $\begin{array}{l}3600-3200 \\
(\mathrm{OH} \text { bonded })\end{array}$ & 3388.74 & & & 3275.73 \\
\hline 2 & $\begin{array}{l}3000-2850 \\
\text { (C-H alkane) }\end{array}$ & & 2964.64 & 2966.29 & 2965.45 \\
\hline 3 & $\begin{array}{l}1820-1670 \\
(\mathrm{C}=\mathrm{O})\end{array}$ & & 1676.51 & 1679.57 & 1678.08 \\
\hline 4 & $\begin{array}{l}1680-1620 \\
(\mathrm{C}=\mathrm{C} \text { alkene })\end{array}$ & 1664.87 & 1676.51 & 1679.57 & \\
\hline 5 & $\begin{array}{l}1600-1400 \\
(\mathrm{C}=\mathrm{C} \text { aromatic })\end{array}$ & $1488.30 ; 1401.50$ & $\begin{array}{l}1581.92 ; 1501.96 ; \\
1485.12 ; 1403.23\end{array}$ & $\begin{array}{l}1583.78 ; 1502.13 ; \\
1486.00 ; 1407.16\end{array}$ & $\begin{array}{l}\text { 1583.76; 1502.94; } \\
1486.64 ; 1404.60\end{array}$ \\
\hline 6 & $\begin{array}{l}1400-1000 \\
(\mathrm{C}-\mathrm{F})\end{array}$ & $\begin{array}{ll}1273.71 ; & 1167.20 \\
1071.16 & \end{array}$ & $\begin{array}{ll}1363.75 ; & 1320.94 ; \\
1292.86 ; & 1232.85 ; \\
1167.67 ; & 1145.94 ; \\
1101.99 ; & 1079.69 ; \\
1012.36 & \end{array}$ & $\begin{array}{l}1322.38 ; 1293.73 ; \\
1237.85 ; 1168.52 ; \\
1148.62 ; 1104.38 ; \\
1080.26 ; 1013.25\end{array}$ & $\begin{array}{l}\text { 1363.75; 1320.29; } \\
\text { 1292.91; 1234.79; } \\
\text { 1167.04; 1146.56; } \\
\text { 1102.10; 1079.76; } \\
1012.65\end{array}$ \\
\hline 7 & $\begin{array}{l}1300-1000 \\
\text { (C-O ether) }\end{array}$ & $\begin{array}{ll}1273.71 ; & 1167.20 \\
1071.16 & \end{array}$ & $\begin{array}{ll}1292.86 ; & 1232.85 \\
1167.67 ; & 1145.94 ; \\
1101.99 ; & 1079.69 ; \\
1012.36\end{array}$ & $\begin{array}{ll}1293.73 ; & 1237.85 ; \\
1168.52 ; & 1148.62 ; \\
1104.38 ; & 1080.26 ; \\
1013.25 & \end{array}$ & $\begin{array}{l}\text { 1292.91; 1234.79; } \\
\text { 1167.04; 1146.56; } \\
1102.10 ; 1079.76 ; \\
1012.65\end{array}$ \\
\hline
\end{tabular}

Table-6: Infra red spectrum of PSf/PVDF coated membrane with varying casting thickness after sulfuric acid immersion

\begin{tabular}{|c|c|c|c|c|c|}
\hline \multirow{2}{*}{ No } & \multirow{2}{*}{$\begin{array}{l}\text { Wavenumber } \\
\left(\mathrm{cm}^{-1}\right)\end{array}$} & \multicolumn{4}{|c|}{ Casting Thickness (mm) } \\
\hline & & 0.4 & 0.6 & 0.8 & 1.0 \\
\hline 1 & $\begin{array}{l}3600-3200 \\
(\mathrm{OH} \text { bonded })\end{array}$ & & 3378.39 & 3360.59 & \\
\hline 2 & $\begin{array}{l}3000-2850 \\
\text { (C-H alkane) }\end{array}$ & 2966.18 & 2966.22 & 2966.23 & 3017.21 \\
\hline 3 & $\begin{array}{l}1820-1670 \\
(\mathrm{C}=\mathrm{O})\end{array}$ & 1701.14 & 1684.57 & 1676.55 & $\begin{array}{l}\text { 1763.82; 1721.30; } \\
1690.80 ; 1678.32\end{array}$ \\
\hline 4 & $\begin{array}{l}1680-1620 \\
(\mathrm{C}=\mathrm{C} \text { alkene })\end{array}$ & & & & $\begin{array}{l}\text { 1649.30; 1641.45; } \\
1630.69\end{array}$ \\
\hline 5 & $\begin{array}{l}1600-1400 \\
(\mathrm{C}=\mathrm{C} \text { aromatic })\end{array}$ & $\begin{array}{l}1583.48 ; \quad 1503.02 ; \\
1486.39 ; 1407.11\end{array}$ & $\begin{array}{l}1582.78 ; 1502.54 ; \\
1485.61 ; 1407.38\end{array}$ & $\begin{array}{l}1582.39 ; 1502.78 ; \\
1485.69 ; 1407.22\end{array}$ & $\begin{array}{l}\text { 1510.86; 1501.85; } \\
1460.95 ; 1400.67\end{array}$ \\
\hline 6 & $\begin{array}{l}1400-1000 \\
(\mathrm{C}-\mathrm{F})\end{array}$ & $\begin{array}{ll}1363.57 ; & 1321.20 \\
1292.82 ; & 1235.84 \\
1167.27 ; & 1146.78 ; \\
1103.39 ; & 1012.54\end{array}$ & $\begin{array}{ll}1167.28 ; & 1146.03 \\
1102.56 ; & 1079.62 \\
1012.50 & \end{array}$ & $\begin{array}{l}\text { 1363.30; 1320.54; } \\
\text { 1292.66; 1234.20; } \\
\text { 1167.03; 1146.26; } \\
\text { 1102.72; 1012.13 }\end{array}$ & $\begin{array}{l}1274.63 ; \\
1162.83 ; 1069.64\end{array}$ \\
\hline 7 & $\begin{array}{l}1300-1000 \\
\text { (C-O ether) }\end{array}$ & $\begin{array}{lr}1292.82 ; & 1235.84 \\
1167.27 ; & 1146.78 \\
1103.39 ; & 1012.54\end{array}$ & $\begin{array}{l}1167.28 ; 1146.03 \\
1102.56 ; 1079.62 \\
1012.50\end{array}$ & $\begin{array}{l}\text { 1292.66; 1234.20; } \\
\text { 1167.03; 1146.26; } \\
\text { 1102.72; 1012.13 }\end{array}$ & $\begin{array}{l}1274.63 ; \\
1162.83 ; 1069.64\end{array}$ \\
\hline
\end{tabular}


RASĀYAN J. Chem.

Vol. 11 | No. 1 | 260 - 279 | January - March | 2018

Table-7: Infra red spectrum of PSf/PVDF coated membrane with varying casting thickness after sodium chloride immersion

\begin{tabular}{|c|c|c|c|c|c|}
\hline \multirow{2}{*}{ No } & \multirow{2}{*}{$\begin{array}{c}\text { Wavenumber } \\
\left(\mathrm{cm}^{-1}\right)\end{array}$} & \multicolumn{4}{|c|}{ Casting Thickness (mm) } \\
\hline & & 0.4 & 0.6 & 0.8 & 1.0 \\
\hline 1 & $\begin{array}{l}3600-3200 \\
(\mathrm{OH} \text { bonded })\end{array}$ & & & & 3350.39 \\
\hline 2 & $\begin{array}{l}3000-2850 \\
(\mathrm{C}-\mathrm{H} \text { alkane })\end{array}$ & 2973.09 & 2965.61 & 2968.14 & \\
\hline 3 & $\begin{array}{l}1680-1620 \\
(\mathrm{C}=\mathrm{C} \text { alkene })\end{array}$ & 1670.78 & 1654.15 & 1653.37 & \\
\hline 4 & $\begin{array}{l}1600-1400 \\
(\mathrm{C}=\mathrm{C} \text { aromatic })\end{array}$ & $1432.37 ; 1400.12$ & $1584.89 ; 1431.77$ & 1431.72 & $1604.49 ; 1401.72$ \\
\hline 5 & $\begin{array}{l}1400-1000 \\
(\mathrm{C}-\mathrm{F})\end{array}$ & $\begin{array}{ll}1275.61 ; & 1171.18 ; \\
1069.94\end{array}$ & $\begin{array}{ll}1398.34 ; & 1242.23 \\
1169.47 ; & 1150.89 \\
1105.53 ; & 1069.53 \\
1069.12 & \end{array}$ & $1391.23 ; 1177.22$ & 1131.72 \\
\hline 6 & $\begin{array}{l}1300-1000 \\
\text { (C-O ether) }\end{array}$ & $\begin{array}{ll}1275.61 ; & 1171.18 ; \\
1069.94 & \end{array}$ & $\begin{array}{l}1242.23 ; 1169.47 \\
1150.89 ; 1105.53 \\
1069.53 ; 1069.12\end{array}$ & 1177.22 & 1131.72 \\
\hline
\end{tabular}
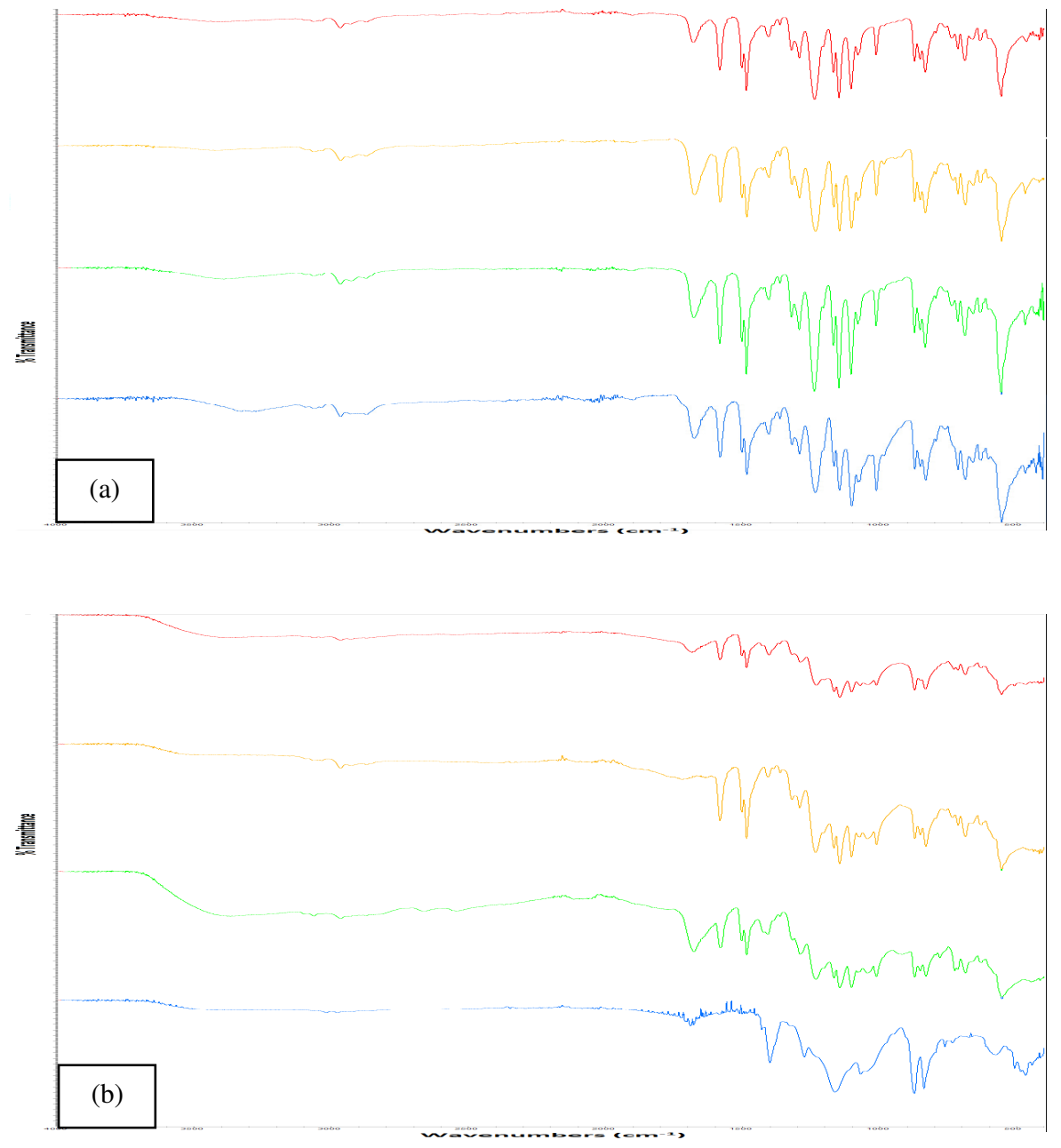
RASĀYAN J. Chem.

Vol. 11 | No. 1 | 260 - 279 | January - March | 2018

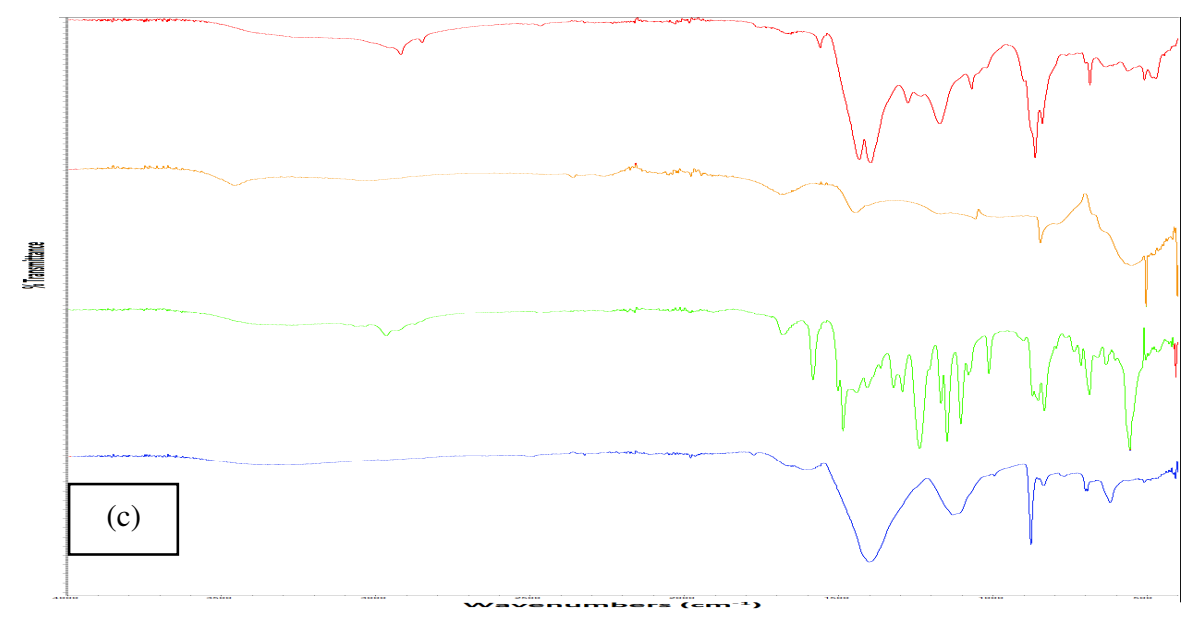

Fig.-11: Chemical resistance of the PSf/PVDF membrane with stirring time variation before (a) and after immersion for $24 \mathrm{~h}$ in (b) acid and (c) alkaline environment
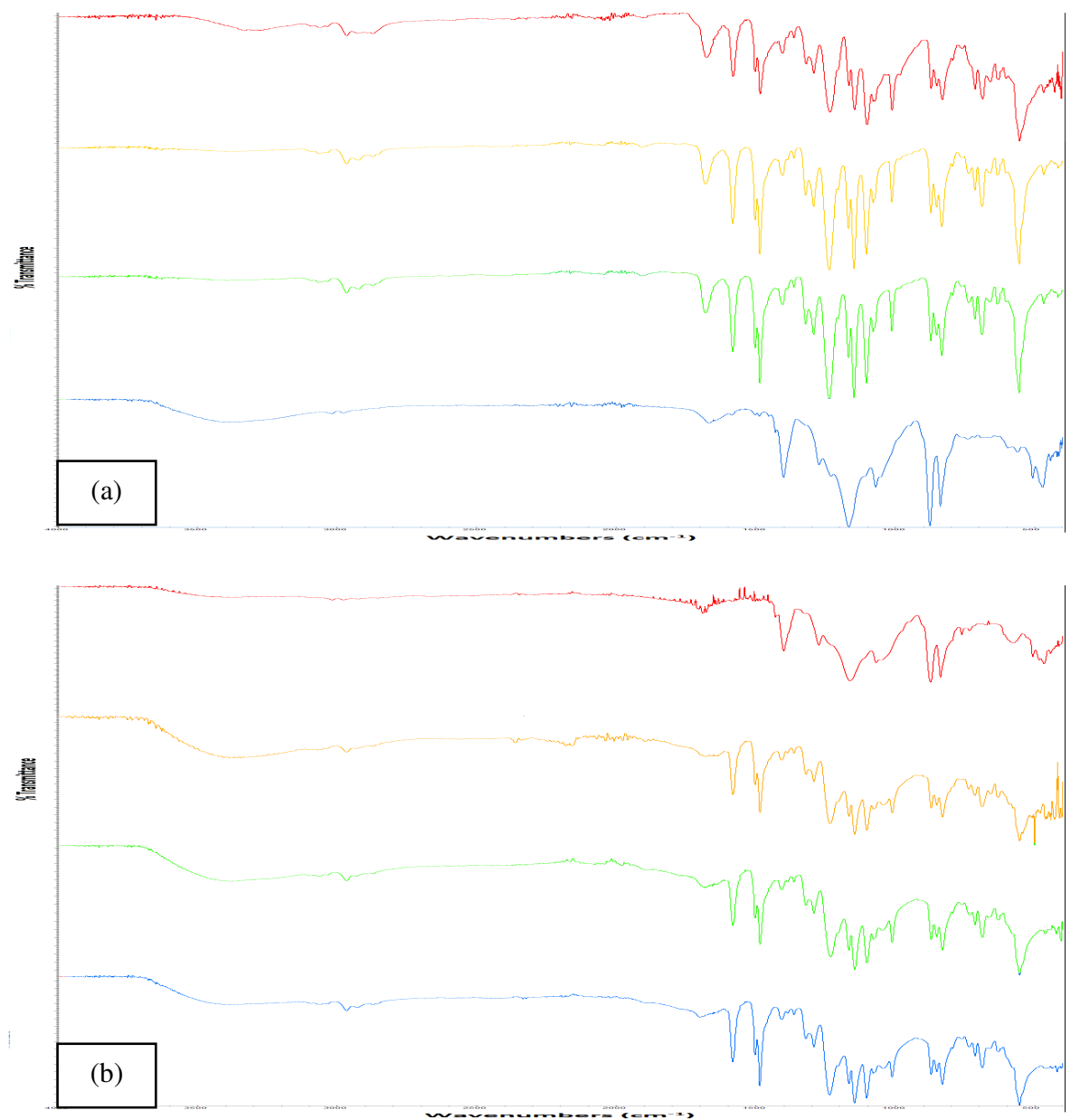
RASĀYAN J. Chem.

Vol. 11 | No. 1 | 260 - 279 | January - March | 2018

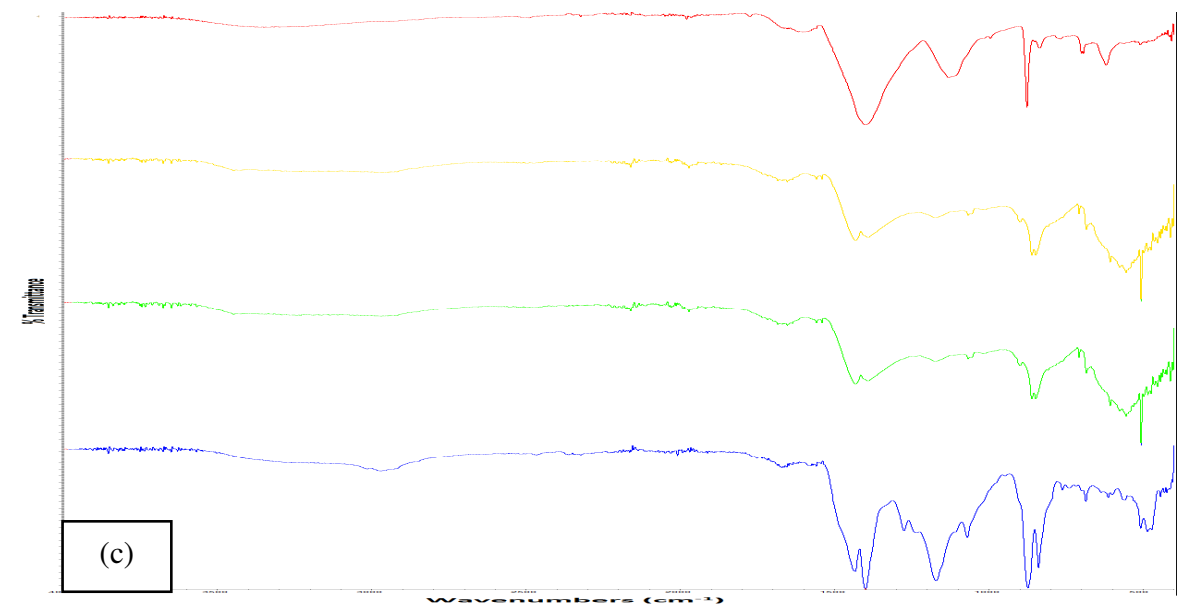

Fig.-12: Chemical resistance of the PSf/PVDF membrane with casting thickness variation before (a) and after immersion for $24 \mathrm{~h}$ in (b) acid and (c) alkaline environment

\section{CONCLUSION}

In this study, adjusting stirring and casting conditions were attempted to tailor and optimize the performance of the PSf/PVDF membranes. The effects of variation in stirring time and casting thickness on the fundamental characteristics of the prepared membranes such as morphology, mechanical characteristics, pure water permeability, also thermal and chemical resistance were systematically investigated. It was found that:

1. Elevation in the stirring time resulted in the greater formation of porous structures with smaller pore sizes and macrovoids, consequently, the formation of membranes with lower pure water permeability.

2. Elevation in the casting thickness resulted in less porous structures with bigger pore sizes and macrovoids, but with higher porous layer thickness, consequently, the formation of membranes with lower pure water permeability.

3. With an increase in stirring times in the testing range, porosity on the membrane change larger, while pore size changes smaller.

4. With an increase in casting thickness in the testing range, porosity on the membrane change smaller, while pore size changes larger.

5. When $7 \mathrm{~h}$ stirring time was used in membrane preparation, the membranes exhibited the maximized permeability.

6. When $1.0 \mathrm{~mm}$ casting thickness was used in membrane preparation, the membranes exhibited the minimized permeability.

7. As the preparation condition component, casting thickness has advantages on higher permeability.

\section{ACKNOWLEDGEMENT}

This work was supported by the project (0001.104/UN38.11-P/LT/2017) supported by Ministry of Research and Technology of Higher Education Republic of Indonesia.

\section{REFERENCES}

1. W. Zhang, J. Luo, L. Ding, M.Y. Jaffrin, Industrial \& Engineering Chemistry Research, 54(11), 2843(2015).

2. R.F. Brady, Polymer Characterisation and Analysis, American Chemical Society, Washington DC, p. 78 (2003).

3. I.-C.K. S. Hong, T. Tak, Y.-N. Kwon, Desalination, 309, 18(2013).

4. Y.-N. Kwon, K. Shih, C. Tang, J.O. Leckie, Journal of Applied Polymer Science, 124(2), 1042(2012). 
RASĀYAN J. Chem.

Vol. 11 | No. 1 |260 - 279 | January - March | 2018

5. J. Ayyavoo, T.P.N. Nguyen, B-M. Jun, I-C. Kim, Y-N. Kwon, Colloids and Surface A: Physicochemical and Engineering Aspects, 506, 190(2016).

6. L. Xu, J. He, Y. Yu, J.P. Chen, Chemical Engineering Research and Design, 121, 92(2017).

7. W.R. Bowen, T.A. Doneva, J.A.G. Stoton, Colloids and Surfaces B: Biointerfaces, 27(2-3), 103(2003).

8. E. Zuriaga-Agustí, E. Alventosa-deLara, S. Barredo-Damas, M.I. Alcaina-Miranda, M.I. Iborra-Clar, J.A. Mendoza Roca, Water Research, 54, 199(2014).

9. L.D. Tijing, Y.C. Woo, J.-S. Choi, S. Lee, S.-H. Kim, H.K. Shon, Journal of Membrane Science, 475, 215(2015).

10. S.E. Cahyaningrum, N. Herdyastuti, A. Firdausa, D. Yanrita, Rasayan J. Chem, 10(3), 959(2017).

11. X. Wang, B. Li, T. Zhang, X. Li, Desalination, 370, 7(2015).

12. J.-H.K.S.L. Kim, Kwon Chung-Hak, Lee Heock-Hoi, Sangho, Desalination, 231, 276(2008).

13. M. Elimelech and W.A. Phillip, Science, 333(6043), 712(2011).

14. R. Semiat, Environ.Sci.Technol, 42(22), 8193(2008).

15. H. Ludwig, Desalination and Water Treatment, 13, 13(2010).

16. M. Sangermano, M.M. Farrukh, A. Tiraferri, C. Dizman, Y. Yagci, Materials Today Communications, 5, 64(2015).

17. P.J. Flory, J. Am. Chem. Soc. 74(11), 2718(1952).

18. L-B. Zhao, M. Liu, Z-L. Xu, Y-M. Wei, M-X. Xu, Chem. Eng. Sci., 137, 131(2015).

19. H. Ohya, S.Shiki, H. Kawakami, J. Membr. Sci ,326, 293(2009).

20. Q.-Y. Wu, L.-S. Wan, Z.-K. Xu, J. Membr. Sci, 409-410, 355(2012).

21. Z.-L. Xu, F. Alsalhy Qusay, J.Membr. Sci, 233, 101(2004).

22. G.J. Ross, J.F. Eatts, M.P. Hill, P. Morrissey, Polymer, 41, 1685(2000).

23. G.J. Ross, J.F. Eatts, M.P. Hill, P. Morrissey, Polymer, 42, 403(2001).

24. M.M. Nasef, N.A. Zubir, A.F. Ismail, M. Khayet, K.Z.M. Dahlan, H. Saidi, R. Rohani, T.I.S. Ngah, N.A. Sulaiman, J. Membr. Sci, 268(1), 96(2006).

25. P.-Y. Zhang, Z.-L. Xu, H. Yang, Y.-M. Wei, W.-Z. Wu, Chem. Eng. Sci, 97, 296(2013).

26. S.P. Nunes, K-V. Peinemann, Membrane Technology in the Chemical Industry, 2nd ed., Wiley-Vch Verlag GmbH \& Co. KGaA, Weinheim, p. 25 (2006).

27. S. I. Voicu, F. Aldea, M. Radut, G. Nechifor, UPB Sci Bull Series B, 70(3), 25 (2008).

28. R.D.C. Ningrum, N. Kusumawati, Int. J. Adv. Sci. Eng. Inform. Tech, 6(5), 716(2016).

29. I. Gustian, Ghufira, D. Oktiarni, Rasayan J. Chem, 10(3), 689(2017).

30. I. Gustian, Asdim, E. Maryanti, Rasayan J. Chem, 9(4), 608(2016).

31. F. Liu, A. N. Hashim, Y. Liu, M. R. M. Abed, K. Li, Journal Of Membrane Sciences, 375(1), 1(2011).

32. Zeman and Zydney, Microfiltration and Ultrafiltration: Principles and Applications, Marcel Dekker, New York, p. 36 (1996).

33. Rabuni, M. F., Sulaiman, N. M. N., Hashim, N. A, Desalination and Water Treatment, 57(1), 1(2016).

34. N.Kusumawati, T. Koestari, S. Muslim, Res. J. Pharm. Biol. Chem. Sci., 7(4), 69(2016).

35. K.D.A. Maharani, N. Kusumawati, Res. J. Pharm. Biol. Chem. Sci, 7(2), 495(2016).

36. W.J. Koros, G.K. Fleming, J.Membr. Sci, 83(1), 1(1993).

37. E. Fontananova, J.C. Jansen, A. Cristiano, E. Curcio, E. Drioli, Desalination, 192(1-3), 190(2006).

38. R. Kumar, A.F. Ismail, M.A. Kassim, A.M. Isloor, Desalination, 317, 108(2013).

39. E. Saljoughi, M. Amirilargani, T. Mohammadi, J. Appl. Polym. Sci, 111(5), 2537(2009).

40. J. Xu, Y. Tang, Y. Wang, B. Shan, L. Yu, C. Gao, J. Membr. Sci, 455, 121(2014).

[RJC-2018/2017] 